O. Birds and Beasts in Medical History

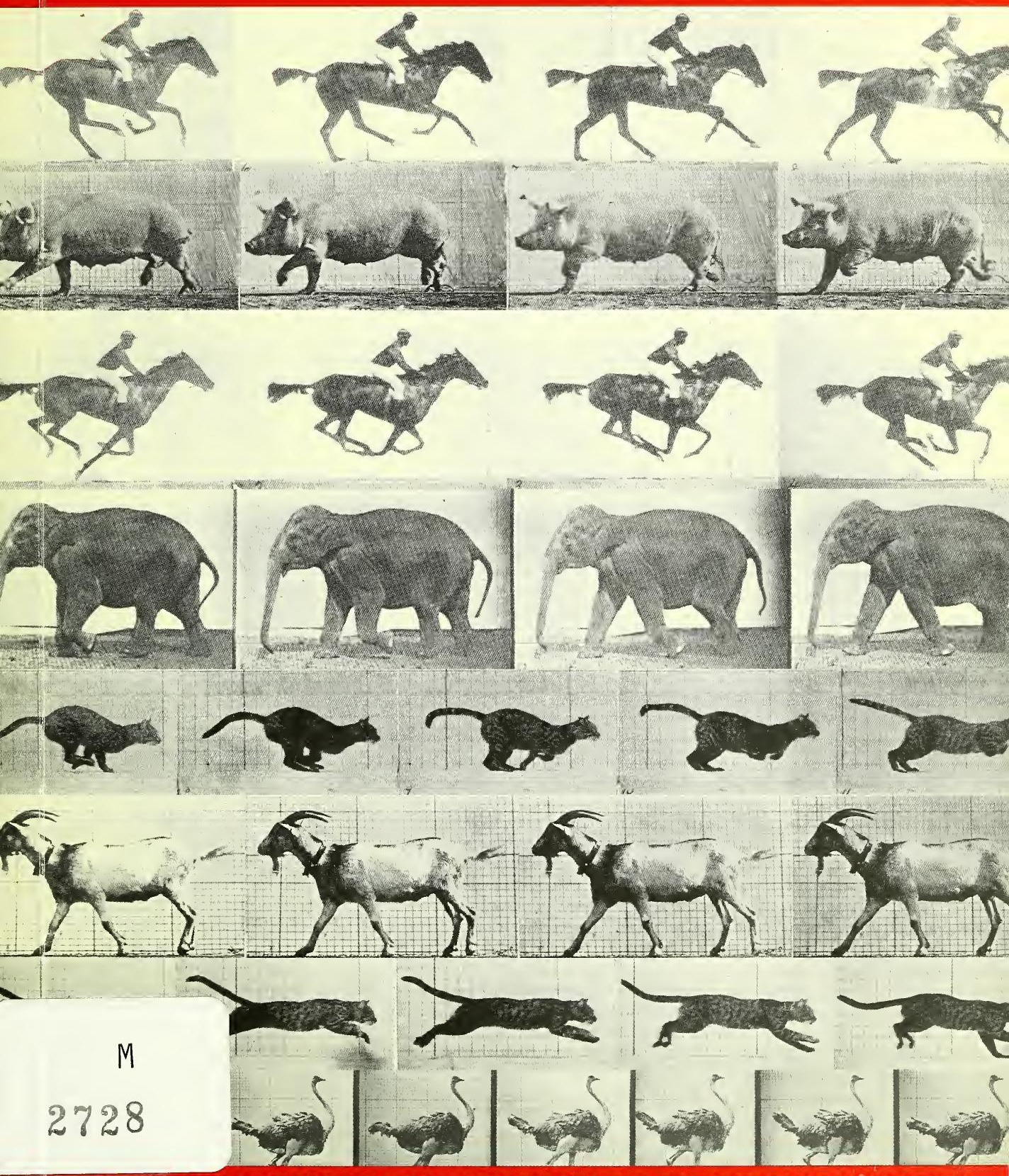




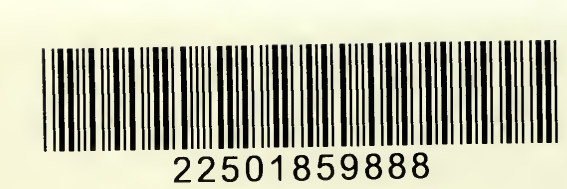




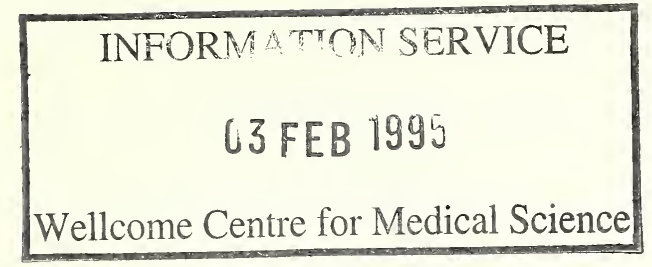

\title{
Animal Doctor
}

birds and beasts in medical history

\author{
AN EXHIBITION
}

AT THE

WELLCOME INSTITUTE FOR THE HISTORY OF MEDICINE

November 1994

\author{
KEN ARNOLD \\ ROY PORTER \\ LISE WILKINSON
}




\title{
CONTENTS
}

\author{
Introduction \\ page 3
}

\section{part I}

Animals, Medicine and Society: Historical Perspectives ROY PORTER

page 4

\section{part II}

Craft to Science: Animal Diseases in Veterinary Texts LISE WILKINSON

page 11

\section{part III}

Animal Doctor: The Exhibition

KEN ARNOLD

page 20

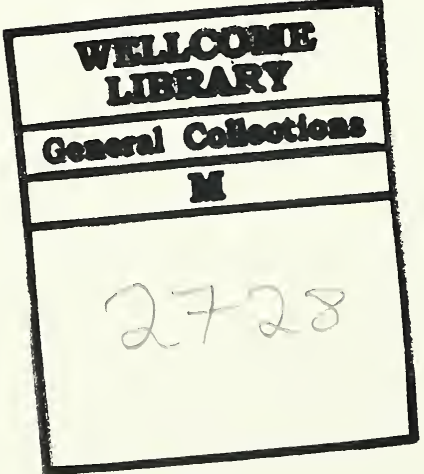




\section{INTRODUCTION}

$\mathrm{T}$ he initial idea for this exhibition stemmed from the desire to mark an important anniversary in the history of the veterinary profession: Queen Victoria's granting of The Royal College of Veterinary Surgeons' charter in 1844.

Assisted by the Library staff, I first set about immersing myself in the Wellcome Institute's collections, a search that revealed literally thousands of books, manuscripts and pictures depicting all kinds of animals - the sick and the well, the whole and the anatomized. Having begun with an interest in veterinarians and their practice, I found myself increasingly drawn to representations of their patients. In order to organize the material, I began dividing it by animal type, a practical measure that proved the most fruitful means of organizing the whole exhibition.

As a result, two divergent interests have fed into this project, interests that are in turn represented in the contributions to this catalogue from Lise Wilkinson and Roy Porter. The exhibition aims, on the one hand, to present material and themes from the history of the veterinary art as it has grown into a modern profession, and on the other, to reflect the social context in which that history has developed. Animal Doctor is thus about animals, doctors and the societies in which both have evolved.

KEN ARNOLD 


\section{HISTORICAL PERSPECTIVES}

The history of veterinary medicine can be fully understood only against 1 the backdrop of a wider understanding of changing relations between man and animals. Today's attitudes towards the living world are full of contradictions. Modern Westerners are fascinated by creatures, witness the popularity of David Attenborough-type programmes on television, to say nothing of commercial promotions like mutant ninja turtles. Yet animals have been banished from our world, and we live in largely animal-free environments. With the exception of birds, the only non-human vertebrate most townsfolk ordinarily see in the flesh are cats or dogs on leads. There is, doubtless, a heightened consciousness of the animal kingdom, thanks to conservationist campaigns and media coverage; but this reinforces the point. Animals are intellectually and emotionally present, precisely because they are physically absent from our profoundly urbanized, concrete civilization.

It never was like that. A hundred years ago, the nation swarmed with animals: wild creatures great and small from deer to rabbits; farm livestock; the cow, pig, geese or chickens that everyone would try to keep to provide milk, eggs, and some winter meat, and, of course, the ubiquitous horses and dogs that comprised so much of the workforce of a pre-industrial society and all this to say nothing of the bestiary of mythical creatures that still haunted the forests of folklore and children's nightmares: dragons, werewolves and other monsters. We are told by demographers that the population of England at the accession of Elizabeth I was very low - a mere three or four million. But this is an odd statistic, for in truth the nation was actually more crowded than it is today, but most of that population was four-footed. Roughly, today, there are three humans for every sheep; in Elizabeth's day, there were three sheep for every person.

In the pre-industrial world, humans and animals lived cheek-by-jowl. A good deal of the human 'kitchen physick' passed down the generations would naturally involve animal products - viper flesh, pike jaw, tortoise penis - not

A version of this essay was orginally published in A History of the Healing Professions: Parrallels Between Veterinary and Medical History. Edited by A R Mitchell. (Wallingford, Oxon, 1993). It is with permission from $\mathrm{CAB}$ International that another version is published here. 
to mention the animal sacrifices so central to magic; and manuscript recipe books from the seventeenth or eighteenth centuries typically juxtapose human and animal remedies higgledy-piggledy: often the cure was identical, only the dose was different.

Around two hundred years ago, Britain was at a crossroads. The nation was in the toils of the first ever industrial revolution. Commerce and manufacturers were overtaking agriculture as the chief source of wealth in what was becoming the workshop of the world. New mechanical powersources were being developed - the steam-engine, the 'iron-horse' - destined to supersede animal traction, a fact ironically echoed by the new measure: horse-power. Millions were migrating to the towns and England was becoming the world's most heavily urbanized society. In 1700, only about $13 \%$ of England's population lived in towns of over 5000 people; by 1850 , more people lived in towns than in the countryside. And fashionable new urban developments put up 'no entry' signs to animals. Leases for squares and crescents excluded pigs and slaughter-houses. London's first by-pass, the New Road, or what we now call the Marylebone, Euston and Pentonville Roads, was designed in part so that Western and Welsh cattle drovers could get their herds on the hoof to Smithfield without having to sully the smart West End and Bloomsbury.

The eighteenth-century shift - to put it in crude terms - from a rural to an urban society involved a critical transformation of attitudes towards animals. It seems that two quite different perspectives were emerging, indeed ones which came to blows in the second half of the nineteenth century.

On the one hand, from the time of William Harvey and the foundation of the Royal Society (1660), there was a long-term increase in the use of animals for research and teaching purposes. There was, of course, nothing new in the practice: pigs, monkeys, and other creatures had been used as proxies for humans ever since Antiquity. Nevertheless, the practice grew. Animals became standardly employed for toxicological testing; Robert Hooke and other early Royal Society luminaries tested theories about gases, respiration and air pressure upon birds; early in the eighteenth century, the Revd Stephen Hales performed extremely gruesome haemostatic experiments upon at least sixty 
experimental subjects, including horses. And thereafter, vivisection proved the major technique for exploring the structure and functions of the nervous system, the nature of sensory motor responses and the pathways of pain.

And even as medical scientists made their notable breakthroughs, protests grew against man's inhumanity towards animals. These took various forms. Humanitarians protested against casual violence in the name of fun swinging cats and the other heartless pastimes exposed in the first of William Hogarth's Four Stages of Cruelty print-sequence. Cruel sports like bullrunning, bear-baiting, and cock-fighting came under attack. Parliament became involved. Eleven bills were introduced between 1800 and 1835 against various forms of cruelty to animals. Most failed, but 1822 saw the passing of the Cruelty to Animals Act, which criminalized animal baiting. And two years later, the Society for the Prevention of Cruelty to Animals was founded. Some public outrage was targeted against the use of animals in medical science.

Among the inferior professors of medical knowledge, [Samuel Johnson asserted,] is a race of wretches, whose lives are only varied by varieties of cruelty; whose favourite amusement is to nail dogs to tables and open them alive; to try how long life may be continued in various degrees of mutilation, or with the excision or laceration of the vital parts; to examine whether burning irons are felt more acutely by the bone or tendon; and whether the more lasting agonies are produced by poison forced into the mouth, or injected into the veins.

Johnson was a great cat lover. Romanticism later created a new stereotype of the experimenter whose intellectual obsessions got the better of his heart: Dr Frankenstein.

Having simmered in the first half of the nineteenth century, disquiet about vivisection boiled over in the 1870s, leading to the RSPCA prosecuting the French biologist, Eugäne Magnan, for experiments conducted before a British Association meeting in Norwich in 1874, and to a popular agitation, linking many anti-doctor and anti-expert causes, for example, hostility to the Contagious Diseases Acts and to compulsory smallpox vaccination.

The rise of animal experimentation, and the animal protection countermovement targeted against vivisectors, sprang from a shared socio-cultural 
matrix; both, paradoxically, were expressions of a changed relationship between man and animals developing with the advent of urban, middle-class society and its attendant more secular and scientific outlooks.

This apparent paradox needs explaining. The agrarian society established from the Middle Ages and continuing through Tudor and Stuart times expressed towards animals practical, no-nonsense attitudes, rationalized by Christian doctrines. Man was superior to the rest of God's creatures, because God had endowed him alone with an immortal soul. The Bible had explicitly given man dominion over the animals, if also a duty of stewardship. The necessities of a hand-to-mouth rural economy, always threatened by death, dictated robust, no-nonsense attitudes. In any case, the sheer physical proximity between man and animals, and the trials of strength involved in taming horses or oxen, or fighting off wild dogs, demanded a blunt assertion of human superiority. Man had to be lord and master.

Things changed from the eighteenth century. Town life grew, and, with it new ideals of elegance and politeness. For the growing bourgeoisie, contacts with the animal world became somewhat attenuated: town-dwellers might now never see animals being born, tamed, and slaughtered, indeed, they might not even ride horses any longer, but go around in carriages. Similarly, the old habit of serving up animals whole at a table gave way to more 'sanitized' presentations of animal food.

Townsfolk increasingly related to animals not through work and play, agriculture and field sports, but through ideas and sentiment. With the Scientific Revolution and the Enlightenment, educated society saw it as its right, duty and pleasure to investigate the natural world from which it was now increasingly divorced. Natural history, botany, zoology, ornithology, bughunting and beetle-collecting became popular fads, involving catching, shooting, dissecting and mounting natural specimens, or keeping fish and birds in tanks and cages, as well as in the zoos that sprang up (London Zoo dates from the 1820s). Any qualms such activities might have aroused were stilled by the thought that they were pursued in the service of the nobler goal of the investigation of Creation. Science, in other words, was the beneficiary of the new physical separation of man from the natural world. The investigative mind would bridge that gap, while reasserting man's superiority, 
not in traditional theological terms - unique possession of a Soul - but through a new ideology: man's sole possession of the scientific spirit. This more urbanized civilization, with its distancing of man and nature, freed the mind for the disinterested contemplation of the living world.

Urban society was not, however, only intellectually curious. It displayed its superior politeness by a new sensibility. Protected and leisured, the affluent bourgeoisie had time and opportunity to cultivate delicate, refined feelings a luxury few had previously been able to indulge. Slaves, noble savages, orphans, the blind, the deaf and the dumb, all became objects of sympathy, charity and vicarious Romantic identification. And so did animals. The new philanthropic initiatives aimed at sparing the sufferings of animals came not from the Church or the political parties, but from the educated urban professional middle classes. It was they who grew alert to the casual cruelties of children towards cats and dogs, they who campaigned against bear-baiting, they who, in the Victorian age, set up societies for the prevention of cruelty to animals in Turkey, Italy, Spain, Greece, North Africa and Japan. It was they who initiated the vegetarian movement (why should animals be slaughtered to gratify gourmet palates?). And, of course, it was precisely such folk who, then as now, spearheaded protests against vivisection.

Divested of intimate daily economic ties with animals, the urban intelligentsia came up with a radically new claim. Humans and animals were basically the same, equals. Forget the soul, both had feelings. In the words of Jeremy Bentham: 'the questions is not, Can they reason? nor, can they talk? but, Can they suffer?'. The new distancing of man from animals which encouraged the scientific mentality thus equally led to the quintessential expression of sameness: the keeping of anthropomorphized pets. Yet these opinion-makers simultaneously emphasized the essential difference of man and animals, but in a new way, not, as within traditional, Christian rural society, by stressing man's dominion, but by arguing that it was man's moral duty to be totally unlike the animals. What bothered the anti-cruelty campaigners was that humans who mucked about too much with brutes became brutalized: Samuel Johnson himself argued that vivisection experiments 'tend to harden the heart'. In his Four Stages of Cruelty (1751), William Hogarth demonstrated the Bully's Progress. The anti-hero, Tom 
Nero, who began life tormenting cats and dogs, turned murderer, was hanged, and finally dissected at the College of Surgeons - implying that the cruelty of the anatomist was but the brutality of the plebs wearing knee breeches and a wig. More broadly, such pioneer vegetarians as Joseph Ritson and Percy Shelley argued that meat-eating turned people sanguinary. The argument about cruelty to animals thus had less to do with the protection of animals than with the protection of society. Cruelty to animals created cruel people, led to cruelty to humans. 'We can judge the heart of a man', argued the German philosopher Immanuel Kant, 'by his treatment of animals'.

Thus there is a paradox, that the same conditions, the same sorts of people, who were to the fore in the experimental study of animals for medicoscientific purposes were also those most concerned to spare the creatures. The explanation is that both arose out of the new distance from the living world created by urban society. Both arose out of a new secular concern to stem suffering, human or animal. Both attitudes fuse, and are juxtaposed, in the painter Joseph Wright's perceptive depiction of the philosopher experimenting with the air-pump. As proof of the vacuum, the breathless bird flutters: will it live or die? Some of the audience are engrossed by the demonstration of the gas laws; others tremble in terror. What the composition symbolically demonstrates is the new separation of man and nature. The dove - once the symbol of the Holy Ghost - is now isolated from the humans by the experimental apparatus. It reminds one of the comparable ambivalences of pet-keeping (for Blake, 'a robin red breast kept in a cage/ Puts all heaven in a rage') and zoological gardens: educational, instructive, or a new voyeuristic cruelty?

What has this to do with the history of animal and human diseases, with the development of English veterinary medicine, indeed, with the foundation of the London Veterinary College in St Pancras in 1791? The answer is that it supplies the necessary intellectual and cultural background.

The story standardly told in the literature is that, up to 1790 , animal medicine in England was disgraced by ignorant and cruel cow leeches, sow gelders, and farriers. Then along came the design, promoted by the Agricultural Society of Odiham, Hants, to establish a veterinary college; a committee was 
formed in London; it received the support of such luminaries as John Hunter, and the patronage of aristocrats, especially the racing fraternity, like Sir Charles Bunbury. Vial de St Bel was luckily to hand; on his death, Moorcroft and Coleman were there to follow him. As a consequence of this, the London Veterinary College was formed, with, at long last, the desire to create properly trained, scientifically educated, diploma-wielding veterinary doctors who, at long last, would practice an enlightened and humane science.

This story is true as far as it goes. But as history it smacks of the ideology that was all the rage around the close of the eighteenth century. The old cow leeches, we are told by the 'Proposals' of the College, were as brutal as the animals they handled and to whom they were obviously too close. An Account of the Veterinary College Since its Institution in 1791 takes note of the 'dangerous practice of farriers, ...daily sacrificing horses, by boldly mangling the organized parts of the body, without knowing anything of its structure' hence the need for proper anatomical knowledge.

The new College would establish distance; it would be elegant, enlightened, urban - a London college. But one where the pupils would be locked in at night so they could not slum it with the animal rabble of the East End. Human doctors such as John Hunter would give the College cachet, elevating the newborn veterinary profession above the vulgarity of gelders and farriers; but veterinary medicine would subsequently achieve its own professional independence - symbolic again of the bifurcation of humans and animals in the modern world.

Herein, of course, lies a story of genuine progress. But, more interestingly, there is a story of attitudes. The birth of the veterinary college in 1791 is inseparable from radical shifts of attitudes about practical and scientific knowledge, rural and urban environments, and, above all, fundamentally changing perceptions of the boundaries between man and animals in a time of transition from agrarian to urban society.

With the Green Movement and the rise of environmental consciousness, it is time to rethink once again our relations to the animal kingdom. With public scares over factory farming and 'mad cow disease', the history of veterinary medicine provides a good starting point. 


\section{CRAFT TO SCIENCE:}

\section{ANIMAL DISEASES IN VETERINARY TEXTS}

Pidemics and epizootics of transmissible diseases, in man and in animals
respectively, are sometimes referred to in self-explanatory terms as crowd diseases or herd diseases. Infectious diseases did, indeed must have, appeared and spread first in animals, which assembled in herds before man settled down to live in communities large enough to sustain outbreaks of transmissible disease. Once human communities were established, and individuals lived in close proximity with their domesticated animals, man became prey to herd disease in more ways than one: some disease agents crossed species barriers, and man himself was infected by the diseases of his animals; in other cases, outbreaks of disease among domesticated animals paved the way for epidemics of other infections in man by lowering his resistance through the stresses of general hardship, starvation, and damage to his fragile economy.

Attempts to combat outbreaks of infection and contagion in domesticated animals developed over many centuries, until in the end the classical, wholly empirical, 'veterinary art' gave way to the professional veterinary medicine of later ages, based on a fuller understanding of individual diseases, of their causes and of their epidemiology. In a parallel development, the early herbal simples and remedies, recommended for man and animals alike, were replaced by more elaborate, though not necessarily more successful, methods of treatment. All these developments were reflected in a steady increase in the volume of published veterinary literature, accelerating with the perfecting of printing techniques from the fifteenth century onwards, although manuscripts existed from much earlier dates. Even the fifth century BC, Hippocratic corpus had contemporary parallel veterinary texts, all preoccupied with epidemics and epizootics, and possible means of prevention and therapy.

Throughout Europe's Middle Ages outbreaks of bubonic plague, most dramatically the Black Death in mid-fourteenth century, painfully illustrated the potential dangers of the interrelationship between diseases of man and of his domesticated animals. Primarily a disease of rats, spread by rat fleas, 
bubonic plague and its concomitant pneumonic plague, attack man when fleas from dead or dying rats encounter man in a search for fresh hosts. The devastating epidemic in 1348-50 followed upon disasters of cosmic proportions in Europe and as far afield as China: widespread catastrophic floods and earthquakes preceded crop disease, which in turn set off animal plagues in sheep and cattle. The ensuing effects on societies living never far from subsistence level are well known, and subsequently spawned attempts to educate the public in the hope of preventing further disasters of such magnitude.

During the following centuries, as printing techniques developed, and beginning in the Italian city states, the issue of broadsheets with advice on detection and possible prevention of disease in domestic animals became increasingly common. The earliest of such veterinary 'fugitive sheets' are, of course, concerned with those most important and valuable of domestic animals, horses and cattle, and indicate the 'seats' of a surprising number of disease, many of which are still known today. In the eighteenth century, the preoccupation with equitation and horse breeding at the French court was one factor influencing the creation of Europe's first veterinary schools in the early 1760s, at Lyons and at Alfort, outside Paris.

Here Claude Bourgelat (1712-79), one of the colourful figures thrown up by the French Enlightenment, laid the foundations of education for a new breed of professional veterinary surgeons. Another factor, which emphasized the need for such special training, could be found in the widespread epizootics of cattle plague which devastated the agricultural economy of Europe in the eighteenth century. By the end of that century, the very obvious need for qualified practitioners of veterinary medicine, rather than the ubiquitous 'quack' purveyors of spurious 'remedies', had spawned schools of veterinary medicine, or veterinary faculties, in universities throughout Europe, from the Italian city states in the south to Scandinavia in the north.

\section{Horses}

In war and in peace, the horse has played a major role in the activities of man in most major civilizations, although in some parts of the world oxen are still preferred as beasts of burden and draught animals. From an early date, the 
horse has also been regarded as a status symbol of no mean order. The beauty of particular breeds was emphasized by the splendid trappings and physical attributes of the nobleman's steed when caparisoned for knightly tournaments, or carrying its heavily accoutred owner to the Crusades, or into other later battles. Highly bred and characterized by the beauty and vigour of its disciplined movements, the horse, whether Arab or lesser breeds, was a valuable commodity; its disease must be recorded, treated with care, preferably prevented. Specialist manuals on the care and the diseases of the horse were written throughout early centuries in China and India as well as in Greece.

Susceptibility to certain infectious diseases is shared by horses with other domestic species and with man himself; anthrax attacks man and all his domesticated animals as well as many wild species, although it is most frequent among the herbivores, especially cattle and sheep, as is brucellosis; and rabies, primarily a disease of foxes and dogs, is also transmissible to other mammals including man when inoculated with infected saliva through the bite of a rabid animal. Far more specific are African horse-sickness, a virus disease transmitted by biting insects, which attacks only the equine species of horse, mule and donkey; and glanders (French morve), a bacterial infection that can, but only rarely does, infect man and other mammals. Where treatment is concerned, the latter two diseases represent opposite extremes of possibilities. In African horse-sickness, affected animals may sometimes recover spontaneously, and treatment is confined to alleviation of symptoms; as for prevention, vaccination is possible, and protection against night-flying insects is essential. Glanders on the other hand, highly contagious and with fatal outcome, has forced the introduction in most countries of legislation disallowing any attempts at treatment and requiring immediate destruction of all diagnosed cases.

Towards the end of the twentieth century, glanders has all but disappeared from Europe, the USA and Canada, but is still present sporadically in Asia, Africa and the Middle East. In the western world, where the main interest in horses today is in the racing community, or where horses are used for recreational purposes, other specific diseases give more cause for concern. From the racing stables and the stud farms, to the hunting field and the humbler pony club, few have even heard of glanders; but everybody has 
heard about, and is on guard against, the commoner virus diseases, notably equine influenza.

\section{Dogs and Cats}

Animal diseases tend to be given attention in literature and history primarily when they threaten to infect man or when, attacking his domesticated animals, they threaten his economy. In either case they can become a public health problem as well as a social problem, and so often pass into the realm of the demographer and the social historian. Since the beginnings of recorded history, major epidemics and epizootics have decimated populations of both humans and animals, and in one way or another left their mark on the course of events. Compared to the effects of such plagues and pestilence described from earliest Greek and Roman times, one disease of animals in the wild, only occasionally transmitted to man's pet dogs and cats, and even more rarely to man himself, has gained unprecedented notoriety throughout history: rabies. It can be traced back in time further than any other infectious or contagious disease; and both lay and scientific authors have chronicled its alarming manifestations in man and in dog, and the distressing course of the clinical disease and its fatal outcome, with great attention to detail.

As far back as the twenty-third century BC the 'mad dog' had a place in legal documents in Mesopotamia - we may note that compensation claimed from the owner of a dog causing death by its bite was considerably less if the victim was a slave than if he was a free man. In Britain legal problems in connection with the 'mad dog' were noted in the ancient laws of Wales compiled by Hywel Dda (Howel the Good) in the tenth century. Through the ages, the spectre of the docile and affectionate pet dog (or in some cases, cat) turned raging monster with fatal effects for its owner or whoever else it might succeed in biting, has been well illustrated, and has been reflected in medical and legal literature. In the early nineteenth century one Bernard-Franáois Balzac (1746-1829), father of Honoré de Balzac and a hospital administrator in Tours, suggested the introduction of a tax on dogs, and also proposed outlawing the centuries old practice of euthanasia for rabies patients: suffocation, usually by means of the sufferer's own bedclothes, or victims of a disease so terrifying to behold. 
At the same time, broadsheets were on public display, to warn and inform the passers-by of the dangers of rabid dogs on the loose. Towards the end of the century, Pasteur revolutionized the outlook for those bitten by the introduction of his post-exposure vaccination.

Given much less attention than rabies in popular literature, but of far more importance for populations of pet dogs everywhere is dog distemper, caused by a virus related to those of measles in man and rinderpest in cattle. Attacking mainly puppies and young dogs, the classical type of dog distemper is a serious disease with a high rate of fatality. In Britain in the later twentieth century it is well controlled by the use of early vaccination of healthy puppies, and occurs much less frequently than before. The fact that ferrets also are susceptible, and were kept for research into the disease at the MRC laboratories in London in the 1930s, coincidentally led to the identification of the influenza viruses of man.

\section{Cattle}

In today's world, cattle providing milk and beef for major and minor civilizations belong to approximately a thousand breeds, including 250 major breeds not counting crossbreeds. The numerous existing British and European breeds have evolved since the stone age from a common ancestor: Bos taurus, which probably originated in western Asia. Once domesticated, cattle herds became prey to herd diseases; the best known, most widely destructive and feared, and hence given most attention in veterinary texts, are rinderpest and foot-and-mouth disease.

Rinderpest was known for the best part of the fifteen centuries during which it has been present in Europe, as cattle plague. Like foot-and-mouth disease, it is caused by a specific virus; but where the effects of foot-and-mouth disease are temporary, if serious, rinderpest kills 9 out of 10 animals in an infected herd. During the eighteenth century, beginning in Italy in 1711 with an infected herd from Dalmatia driven through the Euganean hills, it spread south to the Papal States and north and west throughout Europe, including Britain. Where policies of slaughter and destruction of infected animals 'stamping out' - and subsequent import controls, were adopted, the disease disappeared. Where, on the other hand, spurious 'cures' and attempts at 
'vaccination' were used, as in the Netherlands, the disease persisted throughout the century, providing foci for re-introduction elsewhere.

In Britain, bungling by politicians and veterinary authorities caused a serious imported outbreak (from Estonian ports) in 1865-66. Today the disease in no longer extant in Europe and America, but animals in vast areas of Africa and Asia are still subject to rinderpest, threatening food supplies and transport through intermittent heavy losses of domesticated cattle and buffalo. In countries free from the disease, quarantine regulations are in place; elsewhere, effective vaccines are available. The seriousness of the 1865-66 outbreak in Britain was reflected in contemporary literature, both in scientific arguments, and also in sentimental Victorian tracts dealing with the often tragic effects of the disease on the life of families on farms and smallholdings.

Although foot-and-mouth disease is less serious than cattle plague, it is also wider ranging and less species-specific; in addition to cattle, sheep, goats and pigs are susceptible. The virus exists in a number of different strains and types with only partial cross-immunity, complicating control: in 1973 the Wellcome laboratories at Pirbright had more than 140 different strains in cultivation. Sheep, kept for the production of both wool and meat, share with cattle susceptibility to foot-and-mouth disease and anthrax; but for more than two hundred years, scrapie, still of unknown aetiology, was thought to be species specific to sheep. Only in the second half of the twentieth century has scrapie been found to be transmissible to certain other species in certain circumstances. The ill advised feeding of scrapie-contaminated material to cattle has recently caused an outbreak of BSE (bovine spongiform encephalopathy) in Britain. It was an outbreak that could and should have been prevented in the light of current knowledge; it has raised fears of eventual transmission to man, and caused difficulties for British beef producers nationally and internationally.

In the wake of Jenner's observations on the effectiveness of cowpox vaccination against smallpox, the early nineteenth century saw a surge of interest in the various specific animal pox virus diseases. Sheep pox in particular was studied alongside cowpox both in Italy and in Britain. Tracts were published by Luigi Sacco (1769-1836) in 1809, and by James Beart Simonds (1810-1904) in 1848. The accompanying illustrations gave vivid impressions of the effects of pox virus lesions. 


\section{Fowl}

Populations of domestic poultry have of course been as liable to succumb to infectious disease as other domestic animals, especially under stress, when kept in crowded conditions; but historically, their diseases have received less attention than those of the larger mammals, individually more valuable, and less easy to replace. The role of the itinerant fowl merchant - immortalized in the sympathetic, even affectionate, portrait of Papageno in Mozart's Magic Flute - in unwittingly spreading diseases of poultry as well as of cage birds should not be underestimated. Yet it was not until the later nineteenth century that differential diagnosis of major fowl diseases became possible, in the wake of work on chicken cholera by Perroncito in Italy and Pasteur in Paris; and not until 1901 did it become possible for researchers to trace and map a major outbreak of fowl plague - a virus disease later shown to be an avian type of influenza - in its progress through Europe. Its spread conformed very much to the pattern established by the great pan-European epizootic of cattle plague nearly two centuries earlier.

Beginning in Italy in an area between Ferrara and Modena, it was brought across the Alps to Austria with the stock of an itinerant poultry merchant. It proceeded to travel the length of the Inn valley, until it made an appearance at a poultry show at Brunswick. In a classic display of panicinduced wrong and unfortunate decisions, the authorities closed the show and insisted on the return of all birds to their place of origin. Inevitably, numerous fresh outbreaks resulted throughout the German states, causing havoc to the poultry industry. Only one positive result emerged from the ensuing publicity: the cause of the disease was identified as a member of the recently established group of 'filterable' viruses; and half a century later, it came to serve as a model for the study of human influenza viruses.

Other serious crowd diseases of fowl - including wild birds and 'fancy' birds - included fowl cholera, fowl typhoid (a salmonella infection), and fowl pest or Newcastle disease. Fowl pox is, like the other specific pox virus diseases of animals and man, characterized by eruptive lesions, and can be prevented by early use of vaccination. Psittacosis has increasingly occurred in caged parrots and budgerigars, and is readily transmitted to man with unpleasant, even occasionally fatal, results. 


\section{Zoo Animals}

Many of the larger animals regarded today as exotic 'zoo animals' once roamed the European continent. Remains of rhinoceros have been found in rivers and swamps over large areas from Germany to Siberia, and whole woolly mammoths were preserved in the permafrost of Siberia and of the American arctic tundra. In historical times, China, Egypt and Rome were famous for their menageries and aviaries; the rhinoceros was first introduced to Rome by a specimen brought back from his African campaigns by Pompeius Magnus in 62 BC. After the collapse of the Roman Empire little was heard of exotic animals of Europe until Marco Polo described a Sumatran rhinoceros from his travels in the thirteenth century. Elephants, both Indian and African, were, of course, known and indeed played a major role in the wars of the early civilizations, from the battles between Darius and Alexander the Great to the campaigns of Hannibal.

From the later medieval period, European rulers began to keep private menageries, some of which eventually formed the nucleus of public zoological gardens. If, at first, bears predominated in these collections, more exotic inhabitants took pride of place. The Indian (one-horned) rhinoceros in particular became an artist's delight, from Albrecht Dürer's (1515) pen and ink drawing (now in the British Museum), through many later copies and other versions. The text accompanying Dürer's drawing owes much to the elder Pliny's account in his Natural History, which is also responsible for the Renaissance humanists' belief in the inherent hostility between elephant and rhinoceros.

Since the establishment of zoological gardens everywhere, with these and other now 'exotic' species shown to the public and available for study by the professionals, much attention has been lavished on their anatomy, comparative anatomy, and biology, less on their diseases. With single specimens, or at most two or three animals together, on display, there have been few opportunities for the spread of infections. However, worm infestation is an unavoidable fact of life in the animal world, and gave rise, from the early decades of the twentieth century, to an organized study in London. It was a collaborative effort between the London Zoo and R T Leiper's Department of Helminthology at the London School of Tropical 
Medicine, which in the 1920s became the London School of Hygiene and Tropical Medicine. Here parasites from affected zoo animals were studied to facilitate diagnosis and suggest treatment; at the same time, the department could use the parasites they found in their teaching, and sometimes as subjects for $\mathrm{PhD}$ theses and other scientific studies. It became a long lasting and mutually very satisfactory arrangement.

LISE WILKINSON 


\section{ANIMAL DOCTOR: THE EXHIBITION}

\section{INTRODUCTION}

For so long an intimate part of both work and play, the animal kingdom C has always been vital to humans. Even for those who today have little or no contact with them, animals remain an important part of their imagination. The significance of birds and beasts has in turn prompted much concern for their health and welfare. This exhibition examines animal medicine as it has been shaped by the kaleidoscopic roles animals have played in human society.

Changes in political, economic and intellectual life have all contributed to the transformation of the social and emotional place of animals. The industrial revolution had huge consequences for the work they did, while scientific studies strengthened a view of nature in which animals were removed from the human sphere. The nineteenth century also saw the emergence of a nostalgia for a countryside that fewer and fewer people actually lived in, and a swelling of feeling first for the welfare of animals and then for their rights.

Veterinary interest in caring for animals has been present throughout these developments. Its history has been shaped by factors both internal and external to the profession. In this exhibition, anatomy, physiology, and epidemiology, share the stage with social, cultural, and psychological influences. Divided into six sections, it looks at some of the most important species that veterinarians have studied and treated.

\section{INTRODUCTORY EXHIBITS: ANIMALS IN SOCIETY}

From the biblical creation to Pavlov's dogs, and from widows mourning a dead cat to a Dutch menagerie, this selection of images from the Iconographic Collections gives a strong flavour of the extraordinary breadth of roles that animals have played in human society, as well as the range of their treatment in various art forms.

(a) 'Creation'. Engraving by Edmond Charpy. Troyes, early-seventeenth century.

(b) 'The Entry into the Ark'. Engraving. Nineteenth century

Both of these engravings illustrate stories from the book of Genesis. In one, Adam names the animals; in the other, Noah saves them from the Deluge. 
'Second Stage of Cruelty'. Engraving by William Hogarth. 1751

This is part of Hogarth's series 'The Four Stages of Cruelty'. Tom Nero (a pun implying that Tom was in fact no hero) is caught in the first stage tormenting a dog, and by the last, 'The Reward of Cruelty', is shown in an anatomy theatre being dissected. Hogarth published them 'in hopes of preventing' the 'cruel treatment of poor Animals'.

Iconographic Collections

'Human vivisection'. Colour lithograph published in Lustige Blätter. Berlin, c. 1910

The rabbit says 'Now no phoney sentimentality! The principle of free research requires that I vivisect this human for the health of the entire animal world'.

Iconographic Collections

\section{'Il Mondo alla Rovescia'. Hand-coloured engraving. Italian, $c .1810$}

In these scenes from a world turned upside down, animals change roles with each other and with humans.

Iconographic Collections

'Le Premier Tour'. Coloured lithograph by Victor-Jean Adam. Paris, earlynineteenth century

Horse racing developed into the commercialized sport that it is today in the eighteenth century. The print reflects the artistic convention of showing all four legs of a galloping horse extended at the same time. It was the photographer Eadweard Muybridge who demonstrated that the action was serial rather than simultaneous.

Iconographic Collections

\section{Six handlers with many dogs. Photograph. Russia, c. 1904}

These were some of the dogs used by I P Pavlov in his famous series of experiments at the Imperial Military Medical Academy, St Petersburg.

Iconographic Collections (catalogue no. 11931)

'Old Maids at a Cat's Funeral'. Coloured engraving by John Pettit after F G Byron. London, 1789

The association of cats with women, especially widows, spinsters and those on the fringes of ordinary society, is a long-standing one. Iconographic Collections 
'Cattle show at the Baker Street Bazaar'. Wood engraving. London, 1843

The accompanying text describes the 'perfect apparent comfort and ease of the animals', especially in comparison with the 'filthy stys of Smithfield'.

Iconographic Collections

Cock and sparrows in the countryside. Engraving by Francis Place after drawing by Francis Barlow. $c .1700$

Farmyard and countryside fowl have often been employed as a motif symbolizing rural domesticity. The engraving also shows the convention of giving cocks a regal air.

Iconographic Collections

The menagerie of 'Blaauw Jan' in Amsterdam. Etching. Amsterdam, 1751

Menageries were commonly set up across Europe from the sixteenth century on. They were followed in the nineteenth century by zoos.

Iconographic Collections 


\section{FILMS}

Clips from the following films show some of the ways in which the history of veterinary practice has been reflected in moving images.

\section{Film 1}

'Zoo Doctor'. Urban Movie Chats no. 76. 1921

This film shows the work of a veterinary doctor in a zoo. It was produced by the Charles Urban Trading Company.

\section{Film 2}

'Liverpool University School. Clinical Veterinary Medicine and Surgery'. 1929

This amateur footage shows a number of scenes in the University's original Veterinary Hospital. It was filmed by $\mathrm{Mr} \mathrm{C}$ Wentworth Elam.

\section{Film 3}

'Veterinary training of African Natives'. 1936

This film shows the training of students at the Tanganyika Veterinary Department. It was made in Britain by L A Notcutt.

\section{Film 4}

'A Question of Balance'. 1959

This film looks at the use, made by farmers, of nutrition. It was made by the Wellcome Foundation Film Unit for Cooper McDougall and Robertson Ltd.

\section{Film 5}

\section{'Modern Sheep Dipping'. 1963}

This promotional film shows the use of dipping equipment. It was made by the Wellcome Foundation Film Unit for Cooper McDougall and Robertson Ltd.

\section{Film 6}

\section{'Doctor Dolittle'. 1967}

This musical fantasy was based on the stories of Hugh Lofting. In it a village doctor turns from treating humans to animals. The film was directed by Richard Fleischer and distributed by Twentieth Century Fox Film Corp. 


\section{SECTION I \\ HORSES: VETERINARY STUDY}

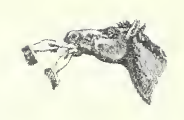

The most important animal in many pre-twentieth century societies was the 1 horse. It was a fundamental unit of power, a defining element of chivalry, essential for transport, crucial in warfare, and ubiquitous in art and sport.

This pre-eminence has resulted in the study of horses being part of zoological enquiries from their ancient beginnings. The evolution of the farrier's practice into the discipline of the professional vet also rested largely on changes in the treatment of horses. It was only after veterinary education had been institutionalized during the nineteenth century that more attention was paid to other animal types. Interest in the horse has been directed at their gross anatomy and at the 'seats' of common diseases that affect them. Considerable attention has also been paid to the two parts of the animal that most directly reflect their usefulness: their mouths and their feet.

\section{EXHIBITS}

Translated as 'Indian book of the horse', this work describes different breeds of horses and the various illnesses to which they were susceptible. Originally composed in Sanskrit, the Persian translation was prepared at the request of the veterinary surgeon to Shāh Jahān (1627-1657). The work contains fifty-seven miniature paintings of horses, of which two are displayed. Much veterinary knowledge flowed back and forth between Indian and Middle Eastern medical traditions. Arabic authors produced a number of works on equine medicine, including the Kitāb al-Nãsirĩ, considered by many to have been unsurpassed in importance until the eighteenth century, either in Europe or the Islamic world.

Persian Ms. 559

\section{I.2 'The superficial muscles of the horse, from behind'. Etching by George Stubbs,} 1766

This is one of the twenty-four plates from Stubbs' great work The anatomy of the horse (London, 1766). The book was aimed not only at other painters, but also those who cared for and kept horses, as well as comparative anatomists. Claimed by many to be 
the greatest animal painter ever, Stubbs (1724-1806) mixed artistic and scientific pursuits. His early interest in anatomy was aroused while working in a Liverpool slaughterhouse. These drawings were based on dissections of horses that occupied him for some 18 months in a barn in Lincolnshire.

Iconographic Collections

\section{I.3 The anatomy of a horse's head. Chalk drawing by Charles Landseer}

Charles Landseer (1799-1879) and his more famous brother Edwin were both apprenticed to the artist Benjamin Robert Haydon, and it was under his tutelage that Charles was taught to imitate Renaissance anatomical drawings. He became keeper of the Royal Academy, to which he bequeathed George Stubbs' drawings for his book The anatomy of the horse.

\section{I.4 Jacques de Solleysel, Le Parfait Mareschal (Paris, 1679)}

This diagram identifies some sixty different maladies associated with specific locations on the horse's body, which are then discussed in the second part of Solleysel's work. The first part deals with the care, management, shoeing, selection and breeding of horses. In Europe, veterinary 'fugitive sheets' using a similar illustration to this were developed as instructional aids, providing information about common diseases of horses to those who used them.

EPB B-sequence

\section{I.5 Markham's Maister Peece. Fifth impression. (London, 1636)}

First published in 1610, Gervase Markham's influential book contained 'all knowledge belonging to Smith Farrier or horse:leech touching the curing of all diseases in Horses'. The sketches in the engraved title-page refer to sections of the book on, for example, diet, blood letting and the use of drenching horns to apply medicines. Markham (1568-1637) turned to literature after an early military career. He himself owned valuable horses, and is said to have imported the first Arab species into Britain.

EPB 4077

\section{I.6 Carlo Ruini, Anatomia del Cavallo (Venice, 1618)}

Remarkably, Ruini (c. 1530-1598) was trained neither as physician nor professional surgeon, but rather as a lawyer. For many, his work on the horse occupies a similar place in the history of equine anatomy to Vesalius' Fabrica in its human counterpart. Like Vesalius', Ruini's work also contained fine anatomical drawings, which were 
copied and modified in veterinary texts until well into the nineteenth century. The illustration shown indicates how the skin was pulled aside to allow observations of the horse's chest cavity.

EPB fol. 5625

\section{I.7 Flavius Vegetius Renatus, Ain Büchlein, vonn rechter unnd warhaffter Kunst} der Artzney (Augsburg, 1532)

Written towards the end of the fifth century AD, Vegetius' Veterinary Art was the first work in the Christian era to be devoted entirely to veterinary medicine. For this reason he has been called the father of the subject. Published initially in 1528, the edition shown here was the first printed in German. The work discusses the transmission and isolation of diseases in many different animals, but concentrates particularly on horses, mules, and cattle.

EPB 6526

\section{I.8 Giordano Ruffo [ $\&$ others] 'Libro dell'infirmita dei cavalli...'. Italian, late- fifteenth century}

The section of this manuscript concerning horse bits contains over a hundred watercolour drawings of different designs, of which one is displayed. Horsemanship and its related paraphernalia was a core element of many courtly and aristocratic cultures. Knowledge of, for example, the minute variations in horse bits could be taken as indicating noble or gentlemanly status.

WMS 706

\section{I.9 Edward Mayhew, The Horse's Mouth Showing the Age by the Teeth (London,} [1849])

Edward Mayhew came to veterinary science after an earlier career as a playwright and actor. This was his first work on the subject. His pioneering research on equine teeth was, he explained, the result of a careful 'study of Nature'. This methodology stood in marked contrast to the 'evil system' he decried in which students simply repeated what teachers taught them. The work gave a 'full description of the periods when the teeth are cut' as well as 'the diseases to which they are subject'.

EPB 36051/B 


\section{I.10 Double-headed tooth rasp. Probably British, nineteenth century}

The idea that afflictions of the teeth were responsible for much horse sickness was a long-standing one. Unevenness in the teeth allowed food that had not been properly chewed into the stomach, which led to indigestion. If left untreated, pain caused by faulty teeth could also leave horses significantly disabled. All this made the tooth rasp an important veterinary tool.

\section{I.11 Jeremiah Bridges, No Foot, no Horse (London, 1752)}

'The Feet of a Horse', explained Bridges, 'like the Foundation of a Building, are the Support of the whole Body'. The focus of veterinary interest on the horse's feet, and to a lesser extent its mouth, reflected a primary concern with the animal's usefulness to humans. A horse with bad feet was, said Bridges, 'useless, or dangerous, to his Rider'. On the work's title page, Bridges described himself as a farrier and anatomist.

EPB 15368/B

\section{I.12 Delabere Blaine, A Domestic Treatise on the Diseases of Horses and Dogs} (London, 1803)

Blaine wrote this book 'so as to enable Persons to practice with ease and success on their own animals'. The title-page illustration of the horse's foot is a reminder of how significant that part of the animal was. Blaine (1770-1845) gained his medical training at the Borough Hospital in London. For the rest of his life he taught, practised and wrote on veterinary medicine, and also sold a range of his own 'Genuine Animal Medicines'.

EPB 1933/B

\section{I.13 (a) Horse shoe. English, 1880-1920. (b) Frost cogs. Probably British, nineteenth century}

In the cool, wet climates of Northern Europe, soft hooves limited the amount of work that horses could do. Applying a metal shoe dramatically increased their usefulness. In the second half of the nineteenth century the traditional form of the shoe was subjected to scientific scrutiny with resulting changes in design. Frost cogs, like those shown, were added to horseshoes to provide extra grip in winter. 
I.14 'Deep searcher' knife. Made by Townsend of Hereford. English, latenineteenth century

Knives like this folding one were used for paring horse hooves. Keeping them clean was advised in order to avoid 'Thrush', a condition especially likely to be brought about, it was thought, by animals standing in the wet. To treat the condition the 'searcher' was used to take off decayed horn before a remedy was applied.

Kindly loaned by the Science Museum

\section{I.15 Traps for horses. Brass body with iron spikes. Probably English}

Used in warfare, these weapons if trodden on could severely disable a horse. Veterinary medicine has long been closely associated with military activities. Indeed, the term veterinary surgeon was coined by the military to distinguish them from others treating humans. Various animals such as mules, camels and even elephants have been used in warfare, but horses were most consistently exploited. They were the basis of the cavalry, they provided mounts for officers, and were widely employed for the transport of supplies and the movement of artillery. In 1880, an army veterinary school was set up in Aldershot.

Kindly loaned by the Science Museum

\section{I.16 (a) 'Never mount a horse in any crowded place', (b) 'Unclothing the beauty} after business is over', (c) 'The test for rick of the back', (d) 'The donkey's only recreation when the work of the day is over' and (e) 'The honest manner of exhibiting the horse's teeth'. Watercolour drawings by Edward Mayhew. Midnineteenth century

Edward Mayhew was a member of the celebrated nineteenth-century literary family. A love of animals seems to have been behind his decision to change his career from the theatre to veterinary practice. He trained at the London Veterinary College, where he was appointed demonstrator of anatomy. These watercolour drawings were done as preparatory sketches for illustrations used in his main works The Illustrated Horse Doctor and The Illustrated Horse Management. They reveal an acute instinct for observing the behaviour both of horses and those who dealt with them. 


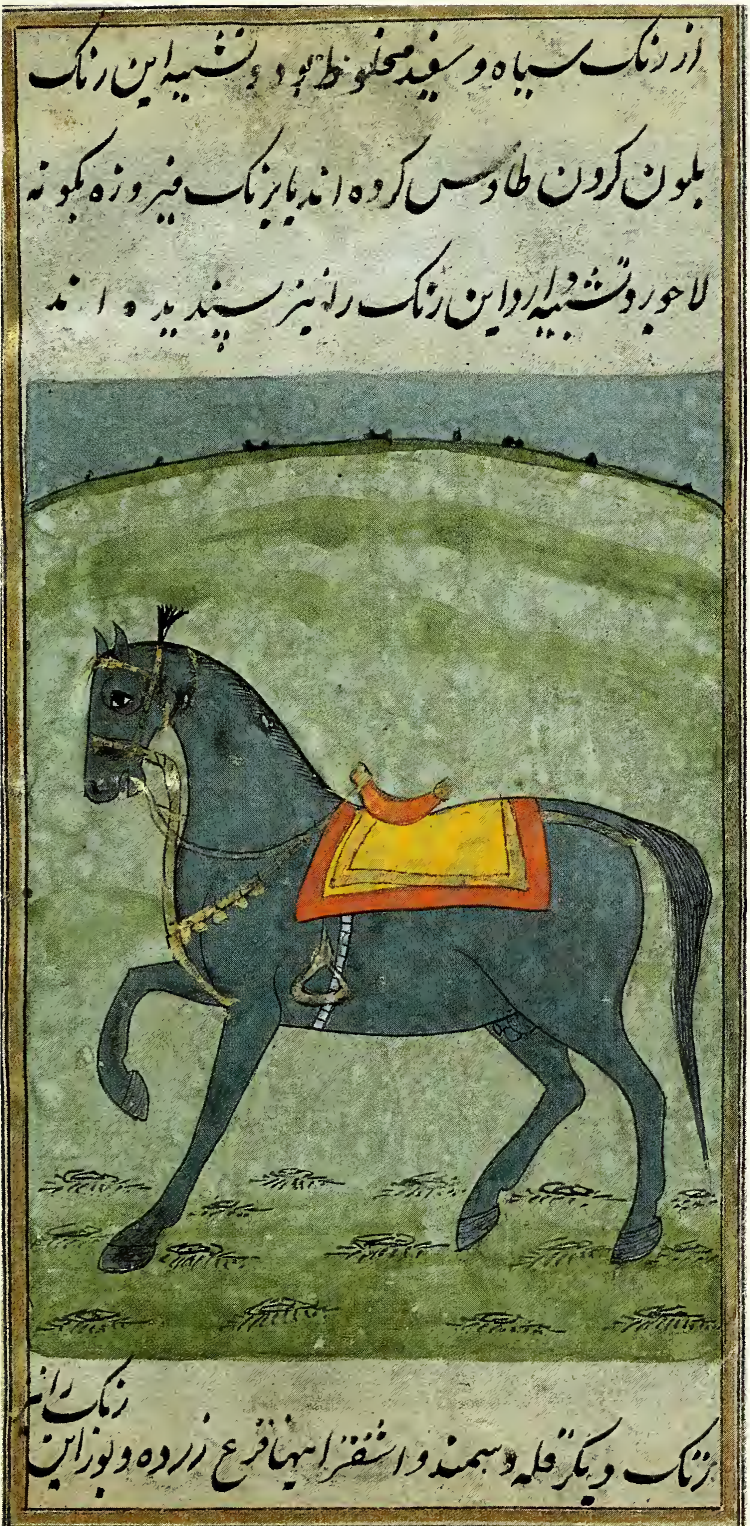

Persian manuscript comprising Faras-nāma-yi Hindi. Item I.1 


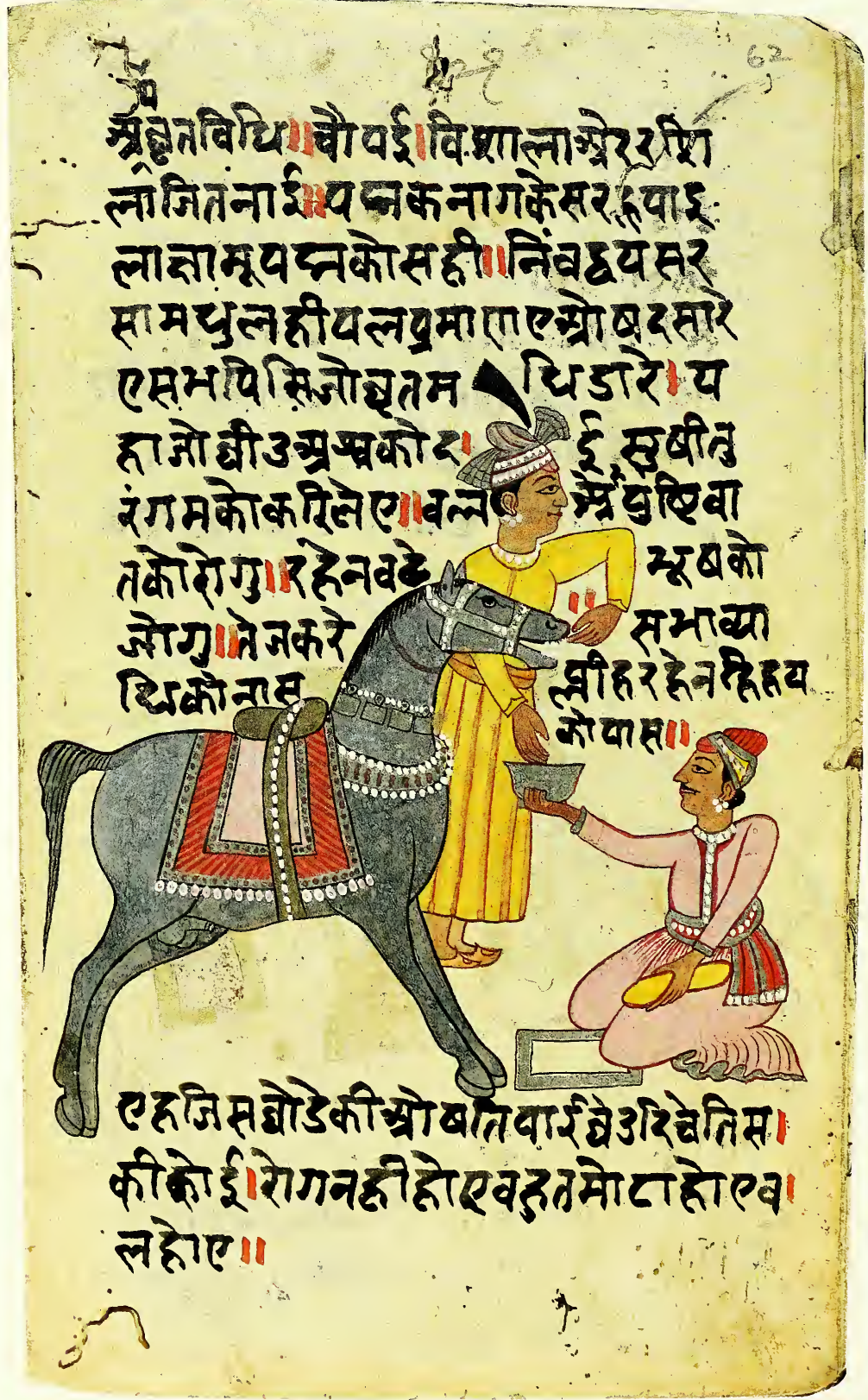

Hindi manuscript containing Ašvacikitsã. Item II.8 


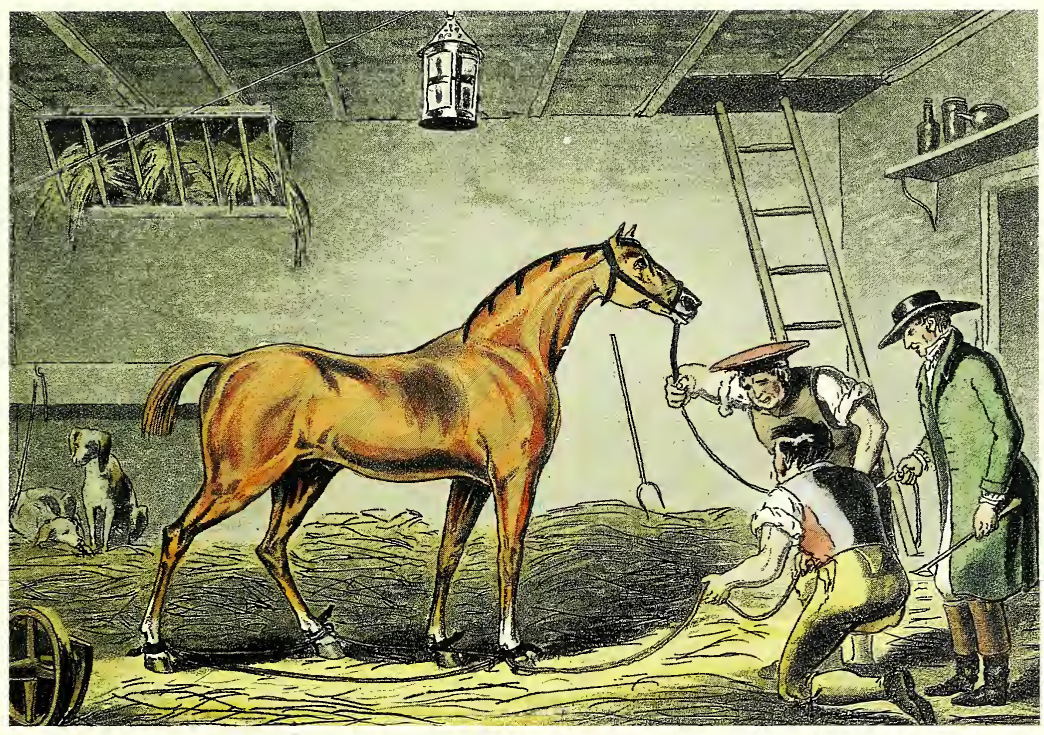

John Rydge. The Veterinary Surgeon's Vade Mecum. Item II.4

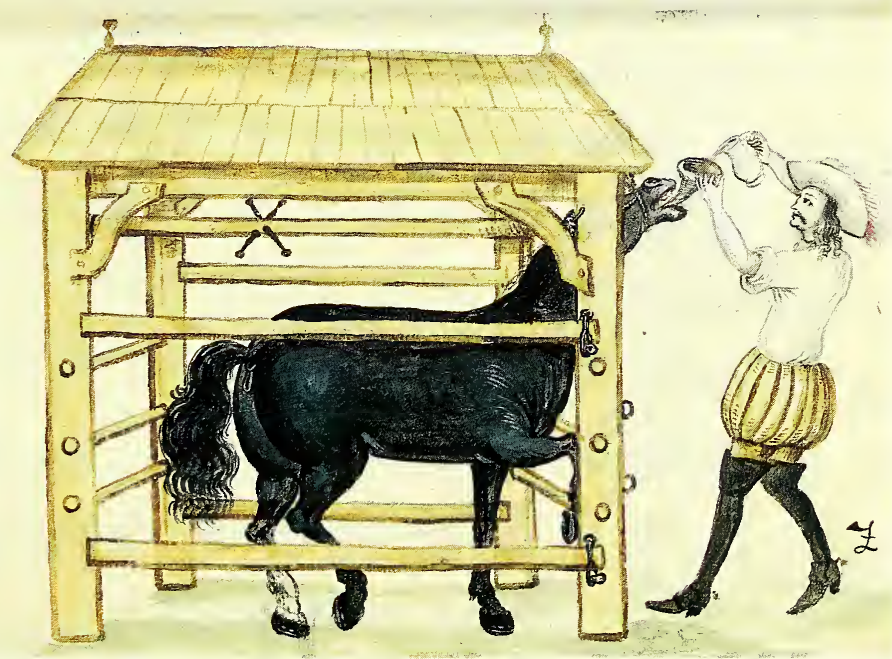

'Pferd-Artz'. German manuscript. Item II.9 


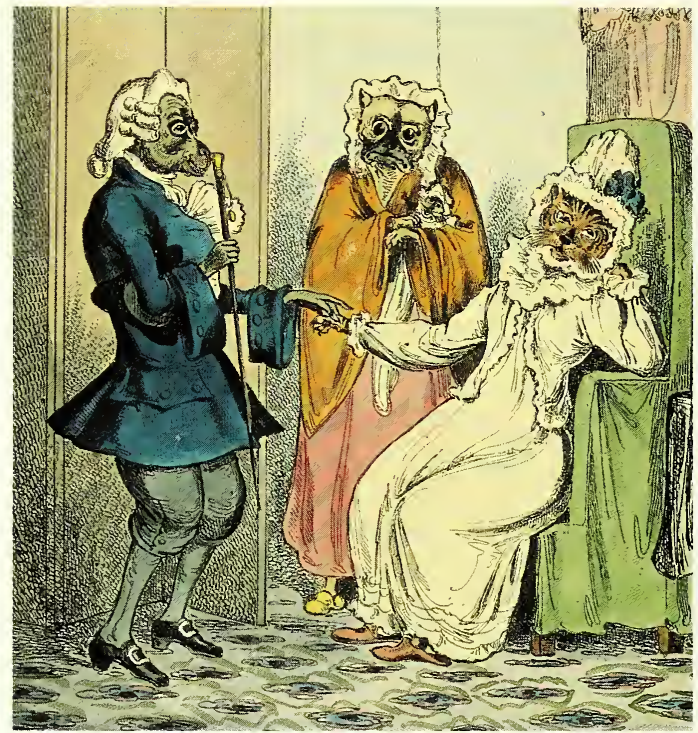

'The Doctor's Visit'. Coloured etching. Item III.1

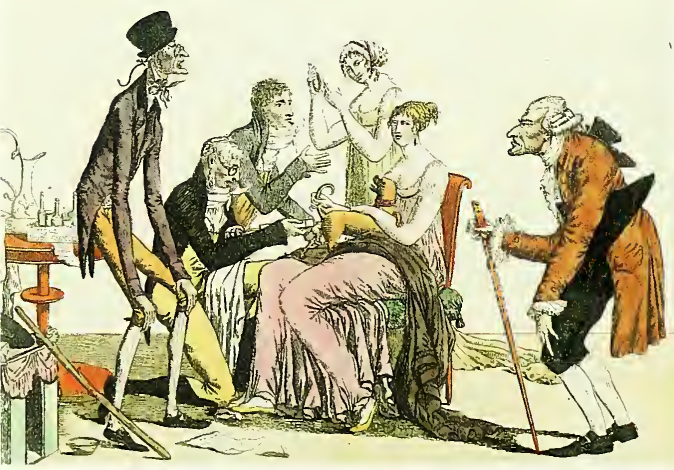

'La Folie du Jour no. 1'. French engraving. Item III.2 


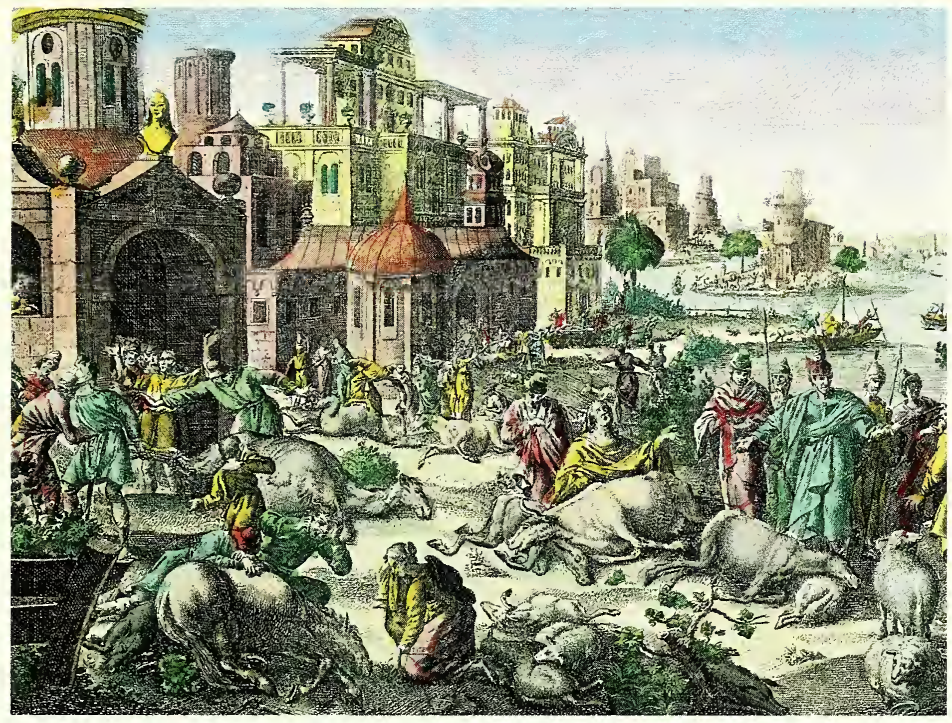

'The Fifth Plague of Egypt'. Coloured etching. Item IV.5

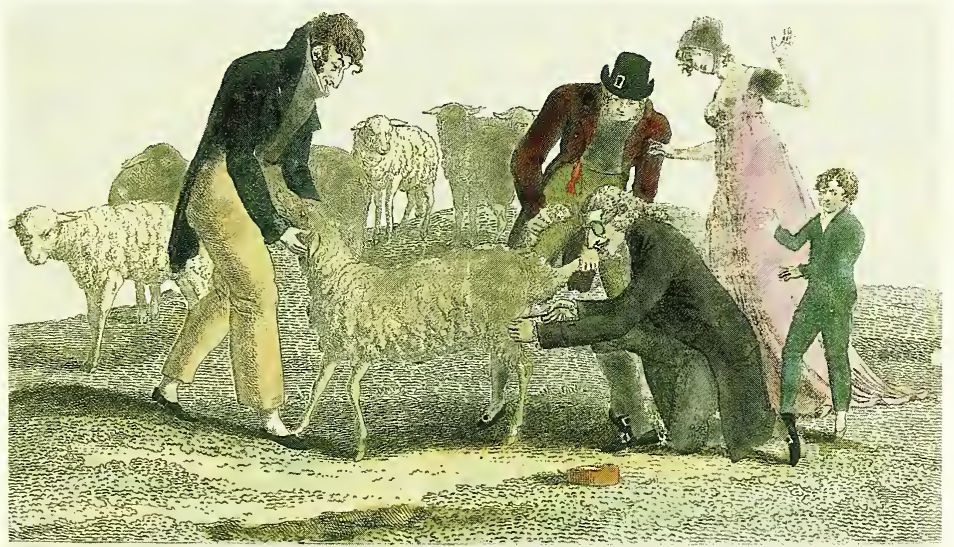

I.F NFC PIUS ULTRA

'Le Nec Plus Ultra'. Coloured etching. Item IV.15 


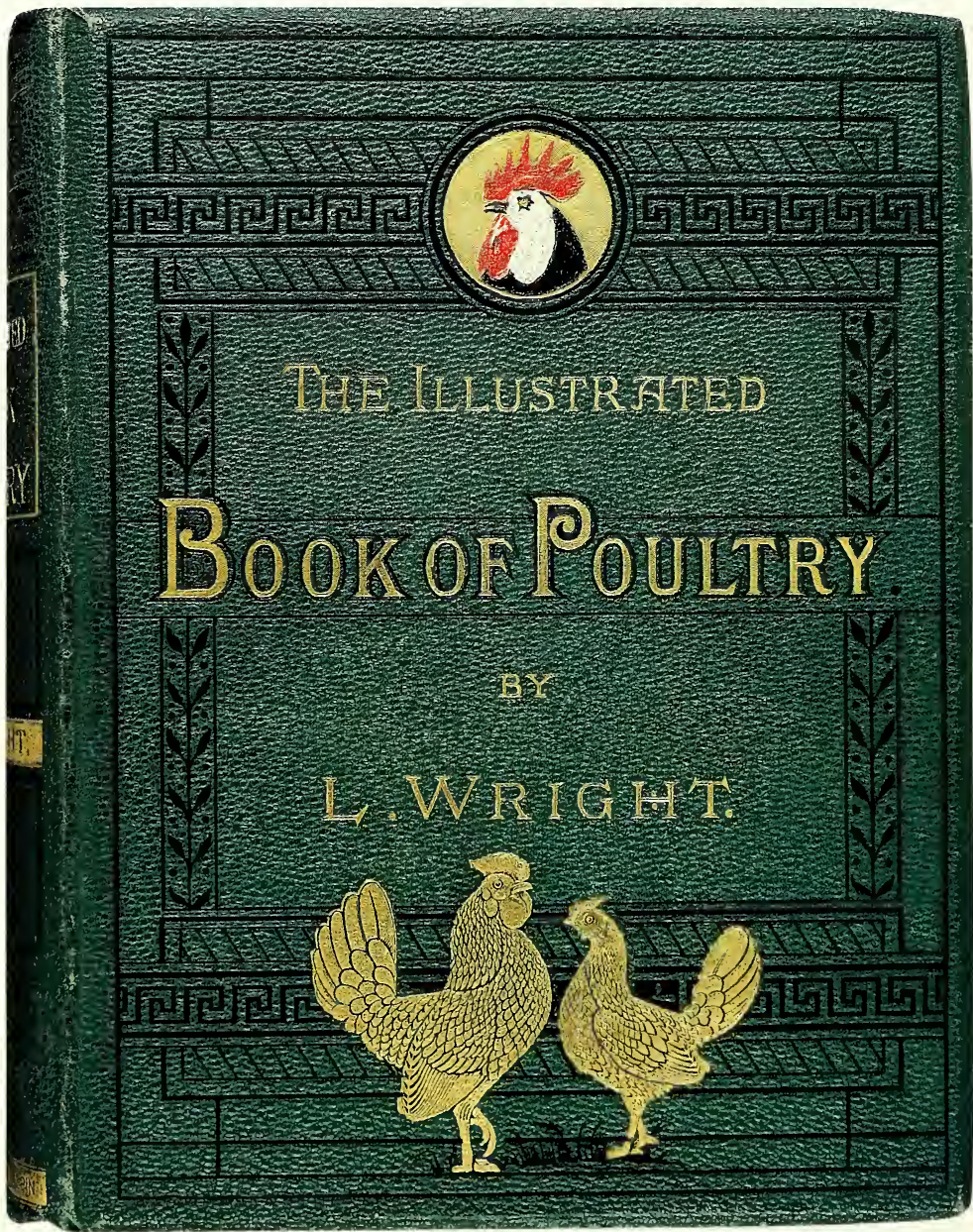

L Wright. The Illustrated Book of Poultry. Item V.1 

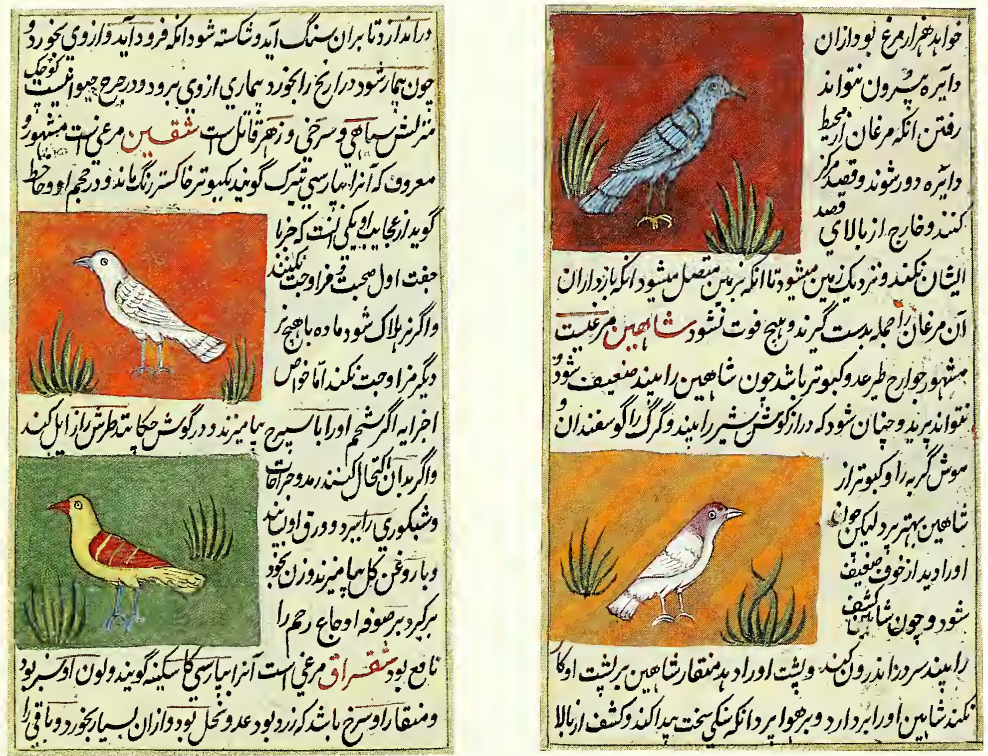

Persian manuscript comprising of Ajä'ib al-makhlũqat va gharã'ib al-mawjüdãt. Item V.7 


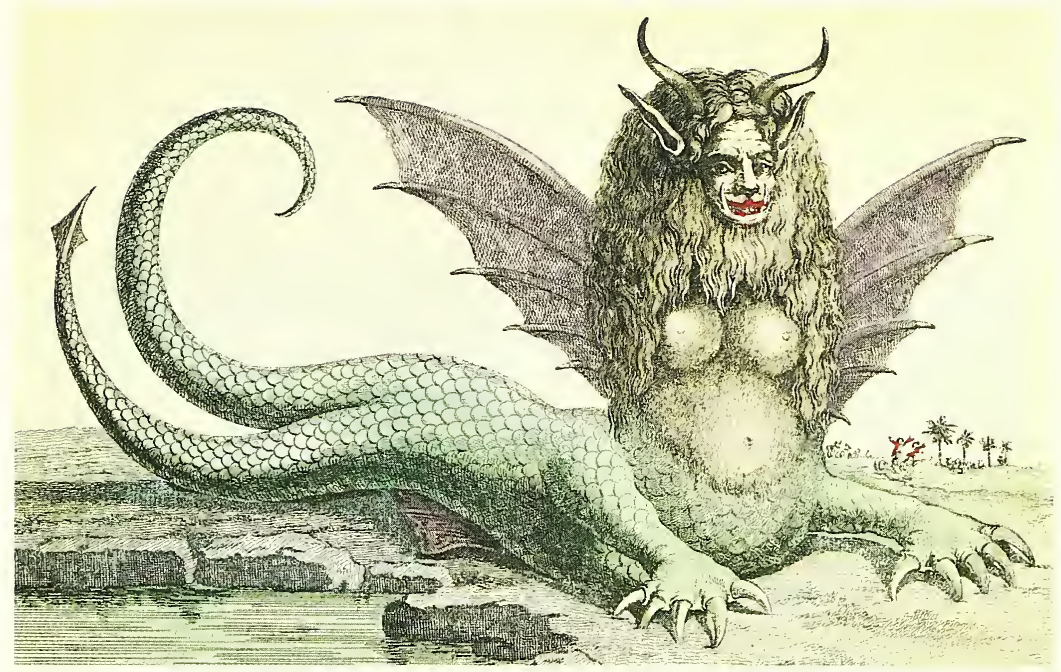

'Harpie'. Hand-coloured etching. Item VI.1

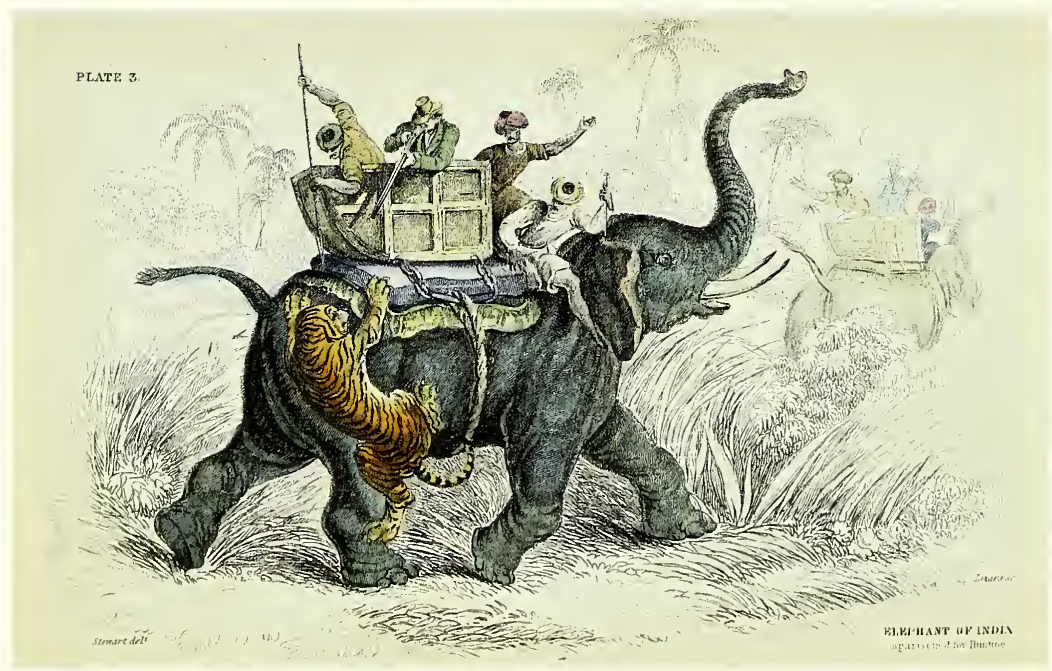

Sir William Jardine, The Natural History of the Pachyderms. Item VI.9 


\section{I.17 'A horse with glanders'. Water colour by Lionel Edwards}

The horse disease-glanders is denoted by a discharge of sticky puss from one nostril, usually the left. Glanders and the closely related farcy, are horse diseases that greatly occupied British veterinary practitioners throughout the eighteenth and nineteenth centuries. The first Glanders and Farcy order was put out by the Board of Agriculture in 1894, in which it directed the slaughtering of infected animals. For a period during the First World War, Edwards was based at the Romsey Remount Depot.

Kindly loaned by the Royal College of Veterinary Surgeons 


\section{SECTION II}

\section{HORSES: \\ VETERINARY TREATMENT}

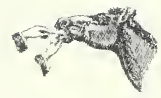

he art of keeping horses alive and well has evolved over thousands of
years. The veterinary concern with equine species has, in part, attempted to deal with the infectious diseases like glanders that have affected them. More routinely, veterinarians have been called on to breed and keep horses for various uses.

Early medical care for horses, like that for humans, was based on herbal simples and remedies. Until the second half of the nineteenth century their treatment by farriers and horse doctors was primarily based on a few standard, though not always effective, operations.

Equine surgeons and physicians have periodically been particularly useful to the military. From early in the twentieth century, as the use of horses for power and transportation decreased, veterinary education evolved to allow its graduates to act as general physicians to many more animals than just horses. As a result, the practice of farriers became more strictly restricted to shoeing horses.

\section{EXHIBITS}

\section{II.1 ‘Arnold \& Sons' Special Horse Slings'. Advertising pamphlet. 1938}

As the illustration shows, one of the biggest problems in the treatment of large animals, like horses, has been supporting and moving their bodies while examining or operating on them. This 'special' horse sling equipped with wood pulley blocks and ropes cost $£ 16$ in 1938 .

Modern Medicine Collection

\section{2 Veterinary instrument set. Made by J J Arnold of London. $c .1840$}

The case for this set of instruments is made of mahogany and lined in felt. Such cases served both to carry the tools of the vet's trade and to impress their clients. The instruments shown were used for various simple operations including bloodletting, which tended to be even more common in veterinary than human medicine. 
II.3 (a) Firing iron with mahogany handle. Made by Burgess \& Co of London.

\section{Nineteenth century. (b) 'Equinoint' booklet. 1910}

By the twentieth century the painful operation of firing was being phased out. This promotional booklet advertised its 'scientific remedy for lameness' as an end to firing: 'there are no curative properties in a red-hot iron', it proclaimed. Firings were performed to treat lameness and strains. It was John Hunter who pioneered enquiries into the effectiveness of 'counter-irritation' - the idea of artificially inflaming the skin to release deeper sources of disability.

(a) Kindly loaned by the Science Museum, (b) Modern Medicine Collection

\section{II.4 John Rydge, The Veterinary Surgeon's Vade Mecum (London, 1827)}

John Rydge wrote this work after thirty years of veterinary experience. It stands as a testament to his belief that there 'is not any thing worthy of the Veterinary practitioners, that may not be compressed within the limits of a volume'. The frontispiece by Theodore Lane is entitled 'Preparing a Horse for an Operation'. The man in the green coat is holding a firing iron, while the horse is being restrained. Though much modern veterinary work is conducted in purpose-built practices and hospitals, country vets are still often called out to barns or fields.

EPB 45292/B

\section{II.5 W Gibson, Farrier's New Guide (1720)}

This eighteenth-century veterinary work is typical both in restricting its interest to the horse and in attempting to reform the practice of the traditional farrier. Underneath the figure, showing the commonest afflictions of the horse, are drawings of the basic veterinary instruments and utensils used in the eighteenth century.

EPB 24552/B

II.6 (a) Edward Mayhew, The Illustrated Horse Doctor. Fourth edition (London, 1862). (b) 'The natural result of pouring medicine down the nose of a horse'. Watercolour by Edward Mayhew

Mayhew wrote this guide to horse diseases in simple language for 'non-professional readers'. He encouraged the horse to be treated not 'simply as a working machine', but instead as a creature 'capable of the tenderest emotions'. The front cover illustration shows his method for passing medicine into the horse through a nostril. The original watercolour sketch, on which it is based, is also shown.

(a) Modern Medicine Collection, (b) kindly loaned by the Royal College of Veterinary Surgeons 
II.7 (a) 'A horse having a sore throat drinking the water returning by the nostril'. (b) 'A instrument for administering a tobacco smoke enema'. Watercolour drawings by Edward Mayhew. Mid-nineteenth century

These drawings were done by Mayhew for his two works on the management and care of horses. As these drawings illustrate, he was an experimental investigator of veterinary techniques. One of his discoveries was that medicines could be administered by passing a tube to its stomach through a nostril.

Kindly loaned by the Royal College of Veterinary Surgeons

II.8 Hindi manuscript containing Aśvacikitsã. Undated, possibly copied in the eighteenth century

Attributed to Nakula, this work includes descriptions of various breeds of horses and details of remedies and treatments for their different ailments. At the opening shown, the horse on the right is being fed with a butter-based tonic. Veterinary works were particularly popular amongst Hindi nobility. Along with horses, elephants were the other animal type they discussed.

Hindi Ms. 191

\section{II.9 (a) 'Pferd-Artz'. Early eighteenth-century German manuscript. (b) Drenching} horn. Eighteenth century

Watercolour illustrations throughout this manuscript depict aspects of the training and treatment of horses. On the page shown, a fettered horse is being given medicine through a drenching horn like the one displayed. The difficult task of getting a horse to take medicine was made easier by pouring it into the animal's upturned mouth.

(a) WMS 3872; (b) kindly loaned by the Science Museum

II.10 (a) 'Fourth Lecture: Philosophical remarks upon the Nature \& effects of Amputation'. Coloured print by E Jakes Howland (London, 1792). (b) Taildocker. Made by Willows, Francis and Butler. London, 1890-1910

The satirical caricature is one of four 'plates exhibiting the men, methods \& machines chiefly employed for the reformation \& improvement of Farriery'. It caricatures the Veterinary College's teachings, and was part of the efforts by farriers to ridicule the new College. The print shows a veterinary surgeon docking the tail of a horse. An example of the instrument he is using is also displayed. The practice of amputating horses' tails declined during the nineteenth century, and is now illegal. 


\section{II.11 'Veterinary Operations'. Hand coloured etching by 'Giles Grinagain'. 1804}

Giles Grinagain is the pseudonym of an unidentified artist. This engraving satirized some of the most commonly practised veterinary operations. Under the heading 'How to heal a sore back', for example, the man in the blue coat is shown applying a firing iron. It was not until the mid-nineteenth century that any form of anaesthetic was available to reduce the pain felt by animals during their treatment.

Iconographic Collections

II.12 Women students examining Bill the horse, with G Parker, College groom. The Royal Veterinary College. 1932

Women have only been accepted into the veterinary profession relatively recently. The Royal College of Veterinary Surgeons admitted its first woman member in 1922. Bill, the horse in the photograph, was brought to the Royal Veterinary College to be treated for lameness, but was then left in the care of the College authorities. An obituary of the animal explained that through his knowledge of the routines, 'Old Bill passed more students through their Animal Management exams than any of the examiners'.

Reproduced by kind permission of the Royal Veterinary College

\section{II.13 Bracy Clark, An Essay on the Bots of Horses, and Other Animals (London, 1815)}

As Clark explained, 'bots [were] insects, whose habitations are the bodies of living animals'. Much of his work is taken up with a history of the recorded attention paid to them. The illustrations show stages in the life cycle of some species of parasites. Clark was a pupil of the highly influential Charles Sainbel. He went on to pursue a lucrative veterinary practice in London.

EPB $17899 / \mathrm{C}$

\section{II.14 Charles Vial de Sainbel, Lectures on the Elements of Farriery (London, 1793)}

Sainbel was educated at the Veterinary College in Lyons. He imported the French patterns of veterinary education when he became the first professor of the Veterinary College in London. He has been credited by some as playing a leading role in the transformation of British farriery into animal doctoring. The College is shown in the frontispiece. A groom is also seen holding a horse's foot while a vet explains to a farrier the natural shape of the foot and the appropriate shoe for it. In the background, ignorance runs away with a mask in her hand. 
II.15 'Shoeing the bay mare'. Lithograph after a painting by Sir Edwin Landseer. Supplement to Glasgow Weekly Herald. 18 April 1891

Veterinary practice very much grew out of the trade of the farrier, who frequently did far more than just shoe horses. The Worshipful Company of Farriers was set up in 1356. From the middle of the eighteenth century the farrier's art was put on a course of dramatic change, which involved energetic attempts to alter its professional standing. When the veterinary profession emerged in its own right in the nineteenth century, farriery came to be more strictly restricted to shoeing. Iconographic Collections

\section{II.16 Enema syringes made from wood and pewter and from bakelite[?]. Probably}

\section{British, nineteenth century}

Enemas were used in therapeutics for a variety of gastro-intestinal complaints. Depending on the fluid introduced into the rectum, they could be used to empty the bowels, kill or expel worms, restrain diarrhoea and even feed an animal that was not able to take nourishment through the mouth.

Kindly loaned by the Science Museum

\section{II.17 (a) Horse razor. Probably British, late-nineteenth century. (b) Horse} clippers. English, early-twentieth century

In much of veterinary medicine, the tools employed have been similar to those used by doctors treating humans. The main difference has often simply been a matter of scale. Extensive overlaps also existed between types of cures used. Prior to the twentieth century, however, the two professions did not find it easy to co-operate. Significant social differences have often led to suspicions and animosity.

Kindly loaned by the Science Museum

\section{II.18 Balling Gun. Probably British, nineteenth century}

Administering solid medicines to horses has always required a certain amount of strength and skill. Instruments, like this one, allowed medicine balls or pills to be given with less risk of injury to the operator. Its passage was often eased by moistening the horse's mouth with oil. Considerable ingenuity was expended on the invention and production of an extraordinary variety of balling guns. It was Joseph Goodwin (1786-1845), veterinary surgeon to George IV, who in the 1820s developed the first such gun.

Kindly loaned by the Science Museum 


\section{SECTION III \\ DOGS AND CATS: PETS}

Teeping animals as companions is, for the wealthy at least, an ancient Icustom. In the nineteenth century, however, as animals came to occupy a less important place in many people's lives, and as the spending power of middle-class purses increased, the habit of having pets rather than working animals expanded throughout society.

The increased popularity generated an elaborate culture of small animal breeding. Intense attention was paid to manipulating characteristics that produced animals that appealed to different classes or individual temperaments. The veterinary profession evolved to suit these needs, greatly expanding its treatment of small animals during the last two centuries. With changes in practice have come new practitioners: more and more women have entered the profession, as they were believed to be especially suited to treating small pets. In treating dogs, the new specialists gave particular attention to rabies, which though not so significant statistically has nonetheless caused great psychological distress.

\section{EXHIBITS}

\section{III.1 (a) 'The Monkey Dentist'. Chromolithograph. (b) Doctor diagnosing a cat} with mumps. Pencil and brown wash drawing. Both English, late-nineteenth century. (c) 'The Doctor's Visit'. Coloured etching. London, 1827

The monkey dentist is shown with a sequence of dog patients before, during and after treatment. The legend on the other drawing reads 'Bad symptoms... decidedly mumps. Recipe some mouse tail soup'. In the third work a foppish doctor is shown paying a house call on a young lady with her mother and baby. Each character is represented as an animal: mule, cat, dog and kitten, respectively. Nineteenth-century satirical artists frequently satirized the excesses of middle-class pet lovers.

Iconographic Collections

\section{III.2 'La Folie du Jour no. 1'. Coloured engraving. French, nineteenth century}

In this satirical print, a group of dandies is shown observing a dog being given an enema. The theme of juxtaposing polite high society figures with such base acts was 
common in the nineteenth century. The subject of enemas further hinted at the mixing of eroticism and medicine. As playthings for courtiers, pets were common even in the middle ages; but it was the enormous expansion of the habit in the nineteenth century that produced a range of responses from delight to disgust.

Iconographic Collections (catalogue no. 16060)

\section{III.3 'Le Goût'. Hand-coloured engraving. French or German, eighteenth century} The scene shows a physician holding a dog while an apothecary pours a 'canine remedy' down its throat. The fluctuations in popularity of different animal species has resulted in the need for the veterinary profession to be able to work in different environments. Larger animals have generally been treated where found; smaller ones have more and more frequently been seen at the owner's home or in a veterinary surgery.

Iconographic Collections

\section{III.4 (a) Queue at Poor People's Out-Patients' Clinic (1929), (b) Professor John} Wright examining a dog (1927), (c) Albert Messervy examining dog's mouth (early 1940s), (d) Florence Bell and Clifford Formston taking X-ray of dog (1930). All Royal Veterinary College

In 1879, the Cheap Practice Clinic, later known as the Poor People's Out-Patients' Department, was established at the Royal Veterinary College. Working animals such as horses made up the majority of patients in the pre-automobile era; but by the earlytwentieth century, small animals such as dogs, cats, birds, rabbits, and even monkeys were becoming more common.

Reproduced by kind permission of the Royal Veterinary College

III.5 'The Dog barber'. Engraving by J Bretherton after drawing by H W Bunbury. London, 1772

Dogs have been kept in Britain for centuries. And their role has always been split between work and play, with a concern for their appearance long accompanying the latter. In the Victorian era the practice of keeping pets became an altogether larger phenomenon. Like many aspects of nineteenth-century culture, the type of pet owned could serve as a badge of social standing. 
III.6 Gaston Percheron, Le Chat, Histoire Naturelle, Hygiène, Maladies (Paris, 1885)

According to Percheron, many previous authors had mistreated the cat. For him, they were just as 'sweet and faithful' as dogs. In the early years of pet-breeding, cats were deemed much less prestigious 'fancy' animals than dogs. The first cat show was organized at Crystal Palace in 1871.

Modern Medicine Collection

\section{III.7 'Notice sur la rage'. Line engraving by $L$ P Baltard. Paris, 1800}

The illustration shows a dog with rabies and a detail of its skull. The printed information describes the signs of rabies and warns the public of the dangers of the disease. In numerical terms, rabies was a far less significant disease than, for example, rinderpest or bovine pleuro-pneumonia; but a number of factors helped make it more troubling: its alarming manifestations, the distressing course it takes, its fatal outcome, the manner of its transmission, its infection of 'man's best friend', and its ready transmission to their keepers.

Iconographic Collections (catalogue no. 5446)

\section{III.8 D Blaine, Canine Pathology; or, a Description of the Diseases of Dogs.}

\section{Fourth Edition. (London, 1841)}

The frontispiece illustrations are accompanied by anecdotes describing the 'virtues and sagacity' of dogs. In the upper picture, a dog rescues its owner who has fallen into a dike in Holland. The lower portrait is of a shepherd dog exhibiting intelligence and devotion to the service of man'. In the works preface, Blaine admits to being, 'by common consent... the Father of Canine Pathology'. Blaine was assistant teacher of anatomy under Sainbel at the Veterinary College in London. Later, he also practised in a London partnership with his pupil William Youatt.

EPB $13937 / \mathrm{B}$

\section{III.9 Dog's head with indication of common parasites. Watercolour drawing by}

\section{J P Megnin.}

Late nineteenth century Megnin (1828-1905) was one of the Royal College of Veterinary Surgeons' first Honorary Associates. He served in the French Army and made a significant contribution to veterinary science, particularly parasitology. By the end of his life he had published over 150 publications.

Kindly loaned by the Royal College of Veterinary Surgeons 


\section{III.10 Vero Shaw, The Illustrated Book of the Dog (London, c. 1880)}

This book is typical of any number concerning kennel management, produced to inform Victorians for whom dogs were an essential part of field sports. It describes the physical features of various breeds, their suitability as either work or lap dogs, and how they should be cared for. The Gordon Setter, displayed, had a reputation for an excellent nose but the lack of stamina in the field. Shaw explained that there was a considerable 'amount of national jealousy and prejudice' about the relative merits of the three types of Setter: English, Irish and Gordon (Scottish).

Kindly loaned by Nigel Allan

\section{III.1 1 Vase, figurine and dog collars belonging to 'Empress'. Nineteenth century}

Dog breeds in the modern sense emerged in the nineteenth century, when concern with detailed distinctions encouraged competition. By the end of the century, some finely bred collies and St Bernards were fetching in excess of $£ 1000$. Most respectable dogs, from the Victorian period on, sported a collar, the nature of which could, along with the breed of the animal, be taken as an index of its owner's social standing. One of the collars exhibited was given as a prize in a competition held in Lancashire in 1838.

\section{III.12 'All in one'. Advertising card}

This shop window display is for a dog food made by Entwistles of Liverpool. Though the expansion of pet keeping was a source of amusement to many, it was also a passion that others could exploit commercially. The trend away from feeding pets scraps from the owners' table or meat unfit for human consumption towards the use of specially prepared foods has emerged in particular during the second half of the twentieth century.

Modern Medicine Collection

\section{III.13 'Cat with wooden leg'. Photograph. New York, early-twentieth century}

The caption on this photograph from the Underwood agency in New York reports that 'This cat is said to be over 20 years old'. 
III.14 Obstetrical forceps for bitches. Made by Coxeter and Son of London. Latenineteenth century

Intervention in dog births was, in the nineteenth century, a contentious subject. Edward Mayhew, author of Dogs: Their Management (1854), argued against the practice. 'Hundreds of bitches, [he complained,] are murdered by the misdirected efforts of Veterinarians'. In the exceptional cases where they were used, he urged that 'the pup should be within the vagina' before employing forceps. Kindly loaned by the Science Museum

\section{III.15 Gray's Dog gag. Made by Arnold and Sons. English, early-twentieth century}

Gags like these were used in restraining dogs during operations. For animals who cannot understand instructions, artificial means of restricting movement during operations are crucial. This design of gag was invented by the Englishman, Gray. As early as the 1840s anaesthetics were used to make operations on animals easier.

Kindly loaned by the Science Museum 


\section{SECTION IV \\ COWS, PIGS AND SHEEP: \\ FARM ANIMALS}

Tn Europe at least, cows, sheep and pigs were all domesticated for human

Lsustenance. From the middle of the eighteenth century, agriculture, particularly in Britain, became increasingly intensified: the demise of manorial farming systems and the enclosure of lands laid the foundations of modern practices. At the same time an enthusiasm emerged for selectively breeding farm animals, in which economics was mixed with sport. The prize animals that this gentlemanly art produced also served to symbolize their owners' self esteem.

The rise in importance of agriculture strongly influenced the development of veterinary practice. The traditional involvement of herdsmen, and in exceptional circumstances, cow leeches or cattle doctors, was replaced by the activities of professional veterinary surgeons. The active role of the profession in halting epidemics of cattle diseases boosted its stature and did much to highlight the need to study and treat species other than the horse.

\section{EXHIBITS}

\section{IV.1 Receipts from John Jones of Usk and W Luff of Oxford. Nineteenth century}

Jones styled himself 'Chemist \& Druggist, Oil \& Colourman' and advertised 'Patent Medicines', and 'Wax \& Sperm Candles' as well as 'Horse \& Cattle Medicines', while Luff stocked 'Genuine Teas \& Cigars', 'Spices, Vinegars, \&c' along with 'Horse \& Cattle Medicines'. Apothecaries and chemists commonly sold medicines for both humans and animals up until the twentieth century.

EPB Hanging files

\section{IV.2 (a) Set of tinned iron drenching horns. English, late-nineteenth century.}

(b) 'Thibenzole'. Card advertisement. c. 1950[?]

These horns were customised for different types of livestock: bullocks, yearlings, sheep or calves and lambs. They were probably supplied with a proprietary medicine. Thibenxole was advertised as the foremost drench 'for all routine dosing of sheep and cattle'. The difficult task of getting an animal to take medicine was made easier by 
using a liquid that could be poured into the animal's upturned mouth. A volume entitled Veterinary Practice at Home (21st edn, 1916) advised that if 'coughing ensues, the head should be instantly lowered, and start again'.

(a) Kindly loaned by the Science Museum, (b) Modern Medicine Collection

IV.3 (a) 'Super Solvitax'. Card advertisement. c. 1950[?]. (b) 'Keating's Persian Insect Destroying Powder'. Advertising sheet. $c$. 1860.

Solvitax was a vitamin rich pure cod liver oil advertised for 'all growing and breeding stock, pigs, poultry and all livestock'. Keating's Powder was meant to destroy 'Fleas, Bugs, Emmets, Flies, ... and every other species of Insect'. Sheep are particularly prone to parasite infestation, and it was William Cooper who developed an effective dip made from arsenic and sulphur in 1834. Cooper's dip and others like it came to replace traditional remedies for 'the itch' based on tar, brimstone, goose grease and tobacco stalks.

Modern Medicine Collection

IV.4 (a) Price list for Day, Son \& Hewitt products (London, 1916). (b) Set of tattooing plates and ink bottle. English, 1950-65

These tattoo plates were used to brand livestock. The price list was included with the Day, Son \& Hewitt's publication Veterinary Practice at Home. The sheep and cattle ear markers illustrated were also used for identification purposes. In law, animals have commonly been viewed simply as property only trivially different from less mobile goods. Since they do not stay put, marking them for ownership is an important part of husbandry.

(a) Modern Medicine Collection, (b) tattooing equipment kindly loaned by the Science Museum

\section{IV.5 'The Fifth Plague of Egypt'. Coloured etching published by the Kaiserliche} Franziskische Akademie. Augsburg, 1775-79

This etching illustrates the part of the ninth chapter of Exodus that describes the 'terrible pestilence' brought upon the Pharaoh's 'grazing herds'. In a Europe ravaged by cattle diseases, farmers and herdsmen turned for help to largely self-taught 'cow doctors' or 'cow leeches'. A chair in cattle pathology was not set up in the London Veterinary College until 1842. James Beart Simonds was the first to occupy it. 
IV.6 'A short horned steer'. Engraving by E Hacker after drawing by W H Davis. London, 1848

The legend on this engraving reads 'Bred by his Grace the Duke of Rutland..., for which the First Prize of $£ 25$ in Class 3 and Silver Medal were awarded at the Smithfield Cattle show'. A sporting interest in cattle breeding emerged as a popular hobby among British gentry in the late-eighteenth century. The animals produced often reflected the owners' sense of their own good breeding. The cattle portraits that prize winners commissioned indicate a profound predilection for fat animals, which were almost invariably depicted in full side view. Iconographic Collections

\section{IV.7 Metal detector being applied to a cow. Photograph. 1951}

This photograph was taken at the Royal Veterinary College, Streatley. The veterinary student, Peter Bennett (left) and Clifford Formston, Professor of Surgery (right) are using a Cintel Metal Detector on a cow that was suffering from a stomach disorder. The instrument was sensitive to ferrous metals, which cattle not infrequently picked up while feeding. Reproduced by kind permission of the Royal Veterinary College

\section{IV.8 Statue of cow by Pierre Jules Méne}

Méne (1810-1879) specialized in animal sculptures. From the eighteenth century on, the passion for prize breeding produced a new artistic subject: cattle portraits. The British have for long shown a strong preference for beef in their diet. Statistics from the middle of the nineteenth century indicate that the English ate some six times as much beef as the French did.

Kindly loaned by Royal College of Veterinary Surgeons

\section{IV.9 William Youatt, The Pig (London, 1847)}

The title-page engravings, done by Youatt himself, show the main breeds of nineteenth-century British swine. Youatt wrote the book because of an 'anxious desire to extend the views of medical science generally, and of my own profession in particular'. He also wrote other books on cows and sheep, and generally worked towards increasing the range of animal species included in veterinary education. EPB 
IV.10 Anatomical Model of the Bull and Anatomical Model of the Pig (London, c. 1948)

These are two of a series of livestock models published by Vinton \& Company for use in veterinary education. They comprised five plates showing external features, skeleton, arteries and veins, muscles, and positions of internal organs. These particular examples were formally held by the Royal Society of Health Library.

Modern Medicine Collection

\section{IV.11 'Manuscript Vétérinaire fait par Marius Bourrelly...' (1839-1841)}

This work was written from lectures given at the Ecole royale vétérinaire de Toulouse by the instructors Gellé, Bernard and Rodet. Though it never seems to have reached the press, the very fine state of the manuscript suggests that it might have been prepared for publication. The illustrations of sheep, pigs and cattle included indicate that they were all at least mentioned in the course of instruction.

WMS 1335

\section{IV.12 Leonard Mascall, The Government of Cattel (London, 1662)}

Mascall's work described 'how to use bulls, and other cattle', and included discussion of 'the Order of Sheep, Goats, Hogs, and Dogs'. It contained advice on, for example, buying and taming oxen and 'remedies against the diseases of the eye'. During the sixteenth and seventeenth centuries a considerable number of publications were devoted to 'philosophical' descriptions of craft skills, with suggestions for their rational improvement. Mascall's is one of a good number that dealt with animal husbandry.

EPB 35766/A

\section{IV.13 G Lowson, The Modern Farrier (London, 1850)}

Lowson's work was dedicated to 'yeomen, farmers, coach-masters, stable-keepers, carriers, cow-keepers, and all other persons engaged in the management of domestic animals'. Lowson quoted with approval a belief expressed by another veterinary author that almost 'all the diseases of cattle arise either from exposure to wet and cold weather, from their food being of a bad quality, or deficient in quantity, or from being changed too suddenly from poor unwholesome keep to rich pasture'. EPB/Suppl. seq. 


\section{IV.14 'Sheep's head with Small Pox'. Coloured print. Mid-nineteenth century}

In the mid-nineteenth century, sheep pox was endemic in Europe. James Beart Simonds, the first Professor of Cattle Pathology in the London Veterinary College, was instrumental in halting its spread in Britain. He successfully diagnosed its occurrence in Windsor in 1847, and was at least in part responsible for establishing an Act of Parliament outlawing the importation of contagious animals a year later.

Iconographic Collections

\section{IV.15 'Le Nec Plus Ultra'. Coloured etching. Paris, $c .1807$}

In the illustration, 'Le Citoyen Marchelli' is shown obtaining matter for inoculation from a sheep. The legend somewhat satirically suggests that the debates about different types of vaccinations were as significant as those surrounding the work of Galileo, Harvey and Descartes. Following the publication of Edward Jenner's discovery of vaccination in 1798 , many animal pox viruses were investigated.

Iconographic Collections (catalogue no. 16149)

\section{IV.16 Bull leader. Probably British, nineteenth century}

This instrument was used to guide and restrain cattle by manipulating their particularly sensitive noses. One of the wooden handles in this example is missing.

Kindly loaned by the Science Museum

\section{IV.17 Hick's milk tester. British, late-nineteenth century}

This small device was used to measure the specific gravity of milk. The lower the figure the more fat the milk contains. 'Milk fever' is a disease that results in loss of consciousness, paralysis and in some cases death. Kindly loaned by the Science Museum

\section{IV.18 'Kerol doser'. Equipment for applying general disinfectant. South Africa,} 1936

Kerol was first introduced into African farms in the 1910s and was employed as a general disinfectant. It could be used on humans, but was marketed particularly for all types of livestock. This improved model of doser ('Mark III') was used by putting the tube down the throat of the animal and pressing the button with the palm of the hand. 


\section{IV.19 Hair ball from cow's stomach. c. 1910}

Many animal species suffer from the accumulation of hair which they ingest by licking themselves. The balls are formed as a consequence of the churning action of the stomach. In early modern Europe, hair balls were seen as objects of considerable curiosity and were regularly displayed in cabinets. Kindly loaned by the Science Museum 


\section{BIRDS: PRACTICAL POULTRY AND NATURAL HISTORY}

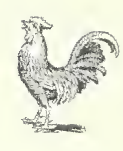

he multiple roles of birds in human society have given rise to a variety of
scientific and medical treatments. In sport, hawking is at least two thousand years old, while the practice of breeding birds has since the nineteenth century represented the lowest level of investment in a consuming passion that at the opposite end of the scale has included horses and farm animals.

The presence of fowl in the farmyard has often figured as the quintessential incarnation of rural domesticity, with the job of tending them ubiquitously defined as women's work. Birds also represented a particularly popular branch of amateur natural history - an accessible part of nature bursting with variety.

In professional veterinary practice, however, birds received little attention until relatively recently. Louis Paster's announcement in 1881 of discoveries concerning the nature of fowl cholera was an important landmark in study of sickness in birds.

\section{EXHIBITS}

\section{V.1 L Wright, The Illustrated Book of Poultry (London, Paris \& New York,} [1873])

This lavish book containing some fifty coloured portraits of prize birds is testament to the commitment of enthusiastic poultry fanciers. Wright thanked the illustrator J W Ludlow for 'deliberately sacrificing mere pictorial "effect" in order to bring out the points of the birds'. The work included 'Schedules for Judging', compiled after 'laborious analysis, demanding... tedious mathematical investigations'. It also discussed matters such as 'houses and accommodation', 'artificial hatching' and 'the utility of "fancy points".

Modern Medicine Collection 
V.2 Elizabeth Watts, Poultry (London, [c. 1930?])

This book was presented as an 'Original and Practical Guide to their breeding, rearing, feeding, and exhibiting'. Ill health in poultry was, said Watts, invariably due to 'a few fertile sources of evil': overcrowding, pampering, or too little care. That the writer is a woman is appropriate since the tending of fowl was traditionally a female domain.

Modern Medicine Collection

\section{V.3 'A dodo'. Engraving by John Le Keux (1783-1846)}

The dodo was first seen by the Dutch when they landed on the island of Mauritius, immediately after their exploration of the passage to the East Indies via the Cape of Good Hope. The subsequent extinction of this species was an early example of the potentially disastrous impact humans can have on the animal kingdom.

Iconographic Collections

\section{V.4 '12 Birds'. Manuscript notes and drawings by Joseph Petiver. 1793}

These drawings are of some of the more striking birds found during the exploration of the North American continent. Petiver describes the bird shown ('The Cardinal Grosbeak') as 'a native of the warmer parts of North America; [that was] imported soon after the first discovery of that continent; [which] soon became a distinguished favorite [sic] in Europe'. Part of the scientific impact of the voyages of discovery was to force existing taxonomies to expand to include myriad new species.

WMS 3721

\section{V.5 George Cuvier, The Animal Kingdom Arranged According to its Organization}

\section{Volume I. (London, 1837)}

Cuvier (1769-1832) did much of his zoological work while at the Muséum d'Histoire Naturelle. It was there that all the collections brought back from the Governmentorganized expeditions were gathered. These were the raw materials that he organized into his classification scheme, on which he built his comparative anatomy. Le règne animal was first published in Paris in 1817.

EPB 19533/B 


\section{V.6 Pierre Belon, L'bistoire de la Nature des Oyseaux (Paris, 1555)}

Belon travelled widely, collecting natural historical information as he went. Along with physical descriptions, his history of birds provided notes about their nests, food, songs and habits. He also included accounts of associated mythology. His particular innovation was the inclusion of large-scale illustrations. The two shown here, in which he drew attention to the similarities in the structure between the skeletons of birds and humans were particularly ground breaking.

EPB 761

\section{V.7 Persian manuscript comprising 'Ajä'ib al-makhlüqat va gharã'ib al-} mawjudãt, composed by Zakariyã’b. Muhammad b. Mahmud al-Kummũní alQazwinĩ (c. 1202-1283)

This encyclopedic work was the first systematic exposition of cosmography in Islamic literature. It subsequently enjoyed considerable popularity throughout the Islamic world. The section devoted to zoology was classified according to an animal's means of defence. Birds were therefore included with animals like hares and gazelles who protected themselves by fleeing. He also described the magical and medicinal properties of the organs of the animals. The manuscript was possibly transcribed in the middle of the nineteenth century.

Persian Ms. 478

\section{V.8 'Ars divinandi' Latin divination tract on vellum. Probably French, fifteenth century}

This manuscript describes a fortune-telling game based on matching zodiac signs with twelve bird types. Ink sketches of the birds are shown. Each is named and has its associated qualities described. A note at the end of the book describes how it was 'written for amusement to preclude idleness and pernicious pastimes among friends when on holiday'.

WMS 79

\section{V.9 Thai manuscript relating to divination. Copied in $c .1870$}

The work is in the traditional form of a folding book, each opening depicting a different animal: tigers, rabbits, elephants, monkeys and, as seen here, cocks. The animals relate to the Chinese calendrical cycle. The four cocks represent different parts of the year. Cocks have been given considerable symbolic power in a variety of different cultural settings: vigilance and spiritual renewal in Greco-Roman mythology, pride in Buddhism, annunciation and betrayal in Christianity, and fame and courage in Chinese art. 
V.10 Raymond Pearl, Frank M Surface and Maynie R Curtis, Diseases of Poultry (New York, 1922)

The authors of this work were biologists in the Maine Agricultural Experiment Station. Their reason for preparing it was to encourage a neglected area of veterinary education: namely avian pathology. The work was compiled by summarizing existing information on the commoner diseases of poultry, their diagnosis, etiology, treatment and prognosis.

Modern Medicine Collection

\section{V.11 'Eagle brain' and 'Guillemot brain'. Watercolour drawings attributed to Denis Gascoyne Lillie $(b .1888)$}

The actual size of the greatly magnified section of the eagle's brain is drawn in black ink in the top left corner of the page. The guillemot was picked up on 'W Renton beach' in 1905. Lillie was educated at Birmingham and Cambridge Universities. $\mathrm{He}$ was the marine zoologist on Scott's last Antarctic expedition. Iconographic Collections

\section{V.12 Canaries Ditchfield's Little Wonder Books, No. 1. (London, [1938?])}

Ditchfield's booklet provided practical information for those who kept 'a Canary as a songster'. In choosing a cage, for example, it advised buying 'the largest you can afford'. Canaries were brought to Europe from the Canary Islands of Madeira and the Azores. They were for a long time employed to detect the presence of dangerous gases in mines. More recently, they have become the most popular cage bird after the budgerigar.

Modern Medicine Collection

\section{V.13 'Pigeon parasites'. Watercolour drawing by Jean-Pierre Megnin. Late- nineteenth century}

Megnin (1828-1905) was a French Army veterinary surgeon who worked extensively on parasitology. He graduated from the Alfort Veterinary School in 1853. He had a particular interest in cage and game birds. He also produced many drawings of birds which he published in his own journal L'Éleveur (The Breeder), a periodical devoted to raising all kinds of birds and animals. Kindly loaned by the Royal College of Veterinary Surgeons 
V.14 Tin of 'Poultry Spice'. English, 1920-40

'Poultry Spice' was advertised as increasing egg supply and keeping chickens healthy. This container was stocked by the chemist Trevithick in Kidderminster.

Kindly loaned by the Science Museum

V.15 Simpson's caponizing set. Made by Willows, Francis and Butler. English, 1870-1920

Caponization, or the castration of cockerels, is carried out to reduce their crowing and inclination to fight. The tools shown were used to open the rib cage and to clasp the testicles. Surgical methods have more recently been superseded by chemical ones.

Kindly loaned by the Science Museum 


\section{SECTION VI}

\section{EXOTIC ANIMALS: BESTIARIES TO ZOOS}

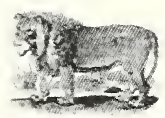

Ain the western imagination. Accounts of exotic animals in bestiaries were among the best known type of medieval didactic literature. Curiosity about such species was further fuelled by voyages of exploration, which brought back both reports of new flora and fauna and a large number of specimens.

Collections of animals and birds were gathered in the menageries and zoological gardens - and if dead in the cabinets of curiosities — that proliferated in European courtly circles from the Renaissance on. In the nineteenth century they were joined by zoos, in which the maintenance and study of captive wild animals symbolized both human mastery of the natural world and colonial mastery over far flung empires. As with so many other species, the shifting roles of exotic animals also influenced the development of veterinary science. In particular, it extended the scope for comparative studies and provided a range of entirely new animals to treat - both in European zoos and in the colonial countries from which they came. Until relatively recently, however, this has resulted more in attention paid to comparative anatomy and biology than the diseases suffered by the animals.

\section{EXHIBITS}

\section{VI.1 'Harpie'. Hand-coloured etching. Paris, 1773-90}

The legend under the etching explains that this carnivorous monster was captured in Chile. It is described as being about twelve feet long, with a man's face, donkey's ears and a lion's main. It was reported as feeding on a cow and three to four pigs a day. It further explained that the King of Spain had ordered the beast to be brought back to Europe to see if the species could be raised there. Iconographic Collections

\section{VI.2 Edward Topsell, The Historie of Foure-Footed Beastes (London, 1607)}

Arranged alphabetically, Topsell's work was an encyclopedic account of all the literature on animals he could find. It included a 'True and lively figure of every beast' 
he described. His descriptions ranged from notes about their names, conditions and kinds, to accounts of their 'virtues' (both natural and medicinal). The Mantichora illustrated on the page shown was typical of the monsters he included in displaying a mixture of characteristics of other animals: the feet of a lion, a human face, a scorpion's tail, and the swiftness of a deer. A mixture of its chin bone and gall could be used to cure the 'falling of the hair'.

EPB 6323

\section{VI.3 'The Bears, in the Gardens of the Zoological Society'. Hand-coloured} engraving by W Panormo after drawing by $\mathrm{H}$ Berthoud. London, mid-nineteenth century

The animal keeper is shown passing food to the bear. Many early zoos encouraged visitors to feed the animals, which provided a relatively safe means of interacting with the exhibits. Bears and elephants were the animals most favoured with such attention. In more recent years, as concern for nutritional value of their diets has increased, 'Please do not feed the animals' signs have become ubiquitous in zoos.

Iconographic Collections

\section{VI.4 'View of the Elector of Saxony's Bear-Garden, at Dresden in Germany'.} Engraving. London, [1785?]

This plate was published in John Hamilton Moore's $A$ new and complete collection of voyages and travels. Menageries gathered by European royalty and nobility from the Renaissance onwards often formed live counterparts to their other collections of inanimate curiosities kept cabinets and museums.

Iconographic Collections

\section{VI.5 (a) Fanny Parks, Wanderings of a Pilgrim in Search of the Picturesque During} Twenty-Four Years in the East. Volume I (London, 1850). (b) 'Indian vet. goes his morning rounds'. Wood engraving by ETR, published in Punch 3 October 1906

The coloured lithograph in Parks' account of her Indian travels is captioned 'The Camels were being branded for the Public Service and the Spider came to be marked also'. The cartoon in Punch shows an army veterinary doctor inspecting a camel with two artificial legs. It was inspired by a Reuter's news report, which described army doctors having, to their surprise, 'been placed in charge of a couple of thousand camels'. Throughout Britain's colonies, the presence and use of exotic animals, such as camels, proved an enduring source of both fascination and humour. 


\section{VI.6 'Livingstone attacked by the lion'. Lithograph, nineteenth century}

The Scottish missionary David Livingstone spent many years exploring Africa. While lion-hunting at Mabotsa in 1843, he was brought to the ground by a lion which crushed his left shoulder and left him permanently disabled. The European idea that the lion was king of the beasts gained wide currency in medieval bestiaries. While zoos allowed colonial wildlife to be tamed within the context of the homeland, the thrill of encountering them in the wild catered to a thirst for danger. The nineteenth century saw the establishment of the practice of big game hunting, with many animals thereby ending up as trophies hung in the houses of the gentry.

Iconographic Collections

\section{VI.7 W Gilchrist, A Practical Treatise on the Treatment of the Diseases of the Elephant, Camel \& Horned Cattle (Calcutta, 1851)}

Gilchrist was a surgeon in the Madras Medical Establishment. This work included 'a description of the medicines used in the treatment of their diseases' and 'a general outline of their anatomy'. The illustration of the profile of an elephant's head is labelled 'The best line of direction for shooting the animal'. The work reflects both a natural historical curiosity about its subject, and the practical concerns of the English in the colonial India.

RAMC Collection

\section{VI.8 (a) Students in the Royal Veterinary College's Anatomy Museum.}

\section{Photograph. 1937. (b) 'Knock-hocked elephant'. Photograph. 1925}

The animal skeletons that can be seen in the Museum are those of a hippopotamus and an African elephant. Skeletons kept in museums have frequently been used in veterinary education. In the other photograph, Dr Vevers, a zoo superintendent, is about to take a plaster cast off the elephant, Oojah. The presence of exotic animals in zoos created a need for at least part of the veterinary profession to learn how to treat them. (a) Reproduced by kind permission of the Royal Veterinary College, (b) Iconographic Collections 
VI.9 Sir William Jardine, The Natural History of the Pachyderms, or ThickSkinned Quadrupeds (Edinburgh, 1836)

This volume was published as the fifth in the series 'The Naturalist's Library. Mammalia'. Jardine explained that the order of pachyderms, which included elephants, rhinoceros and wart hogs, were 'creatures of great utility when domesticated'. Elephants gained a particularly honoured place in the European imagination from reports of their crucial role as 'servants' in Indian Society and commerce. The plate shown is of an Indian elephant 'caparisoned for hunting'.

EPB 30315/B

\section{VI.10 'The Craft in Danger'. Etching and aquatint by John Kay. 1817}

This satirical etching was inspired by the debate over the proposed chair of comparative anatomy at the University of Edinburgh. The image shows the proposed professor, Dr John Barclay (1758-1826), riding into the University on an elephant's skeleton. Those attempting to stop his entrance include Dr Thomas Hope (1766-1821), shown impeding the elephant with a rope and Prof. Robert Jamieson (1774-1854), brandishing a narwhal horn and protesting that the new knowledge is not 'mentioned by the illustrious Werner' - a reference to the geologist Abraham Werner (1749-1817).

Iconographic Collections (catalogue no. 10782)

VI.11 'The Cayman Crocodile, and Amphysbaena Viper'. Coloured etching by $\mathrm{J}$ Pass after drawing by J E Ihle. $c$. 1800

The idea that crocodiles shed tears is an ancient one, which was commonly associated with the notion that they did so to lure their prey. An early Bestiary described how a crocodile killing a man 'remains inconsolable the rest of its life'; while Shakespeare spoke of 'the mournful crocodile/ With sorrow snares relenting passengers'.

Iconographic Collections

\section{VI.12 Veterinary Record. 30 January 1897, p.401}

The article is headed 'Snake photo'd by Röntgen Rays Camera in Georgetown, Demerara, Brit. Guiana, Dec. 1896'. Two lizards in different stages of digestion were identified in the body of the snake. The potential application of X-rays in veterinary medicine had already been discussed in a veterinary journal in 1896, less than a year after Röntgen's initial discovery. In it, an X-ray photograph of a cat was shown, which had been used in diagnosing its lameness.

Kindly loaned by the Royal Veterinary College 


\section{VI.13 Narwhal tusk. Nineteenth century}

Narwhals are arctic toothed whales. It is the male of the species that have spiral tusks, one of which is displayed. If not actually passed off as one, these tusks were often likened to the mythical unicorn's horns. The medical power of this latter material was, until the eighteenth century, thought to be second only to that of mummified flesh. They were also prized objects of curiosity, with many consequently being found in early museums.

Kindly loaned by the Science Museum

VI.14 (a) Stuffed snake climbing pole. English. Prepared in period 1890-1940. (b) 'The locomotive muscular system of Serpents'. Coloured engraving by J Pass. 1826

The anatomical engraving was published in Encyclopaedia Londinensis. In classical mythology caduceus is a winged staff entwined with two serpents, which was carried by Hermes as a messenger of the gods. The world's first reptile house was opened in the Regent's Park Zoo in London in 1849, with twenty-one species, principally snakes, displayed in a series of glass fronted cases.

(a) Kindly loaned by the Science Museum, (b) Iconographic Collections

VI.15 (a) Rattle snake's tail in specimen jar. Palestine, 1840-1920. (b) Stuffed and coiled snake. French. Prepared in period 1895-97

The jar is English but the snake it contains is identified as coming from 'Palestine'. The coiled snake reputedly bit Albert Calmette in his laboratory in Lille, France in 1897. Much medical interest in snakes has, for obvious reasons, focused on the venom and antidotes against its effects.

Kindly loaned by the Science Museum

KEN ARNOLD 


\section{ACKNOWLEDGEMENTS}

In the research for and installation of this exhibition I have been greatly helped by many people.

Special thanks are due to Nigel Allan, Richard Aspin, David Brady, Chris Carter, Simon Chaplin, Michael Clark, Sally Driscoll, Clare Dunne, Richard Everett, Sophia Flynn, Peter Friedlander, Klif Fuller, Sherwin Hall, Marybeth Hamilton, Geoff Harris, Miss B Horder, Mike Jackson, Fiona James, Jane Kingsley, Jeannette Lake, Stephen Lowther, Anne Marie Margetson, Andrew Melvin, Michele Minto, Roy Porter, Neal Potter, William Schupbach, John Symons, Lise Wilkinson and Marie Williams

ISBN: 1869835360 


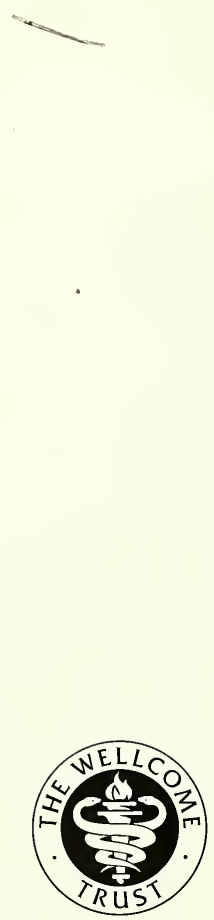